\title{
Trophic modeling of the Northern Humboldt Current Ecosystem, Part I: Comparing trophic linkages under La Niña and El Niño conditions
}

\author{
Jorge Tam ${ }^{\mathrm{a}, *}$, Marc H. Taylor ${ }^{\mathrm{b}}$, Verónica Blaskovic ${ }^{\mathrm{a}}$, Pepe Espinoza ${ }^{\mathrm{a}}$, R. Michael Ballón ${ }^{\mathrm{c}}$, Erich Díaz ${ }^{\mathrm{a}}$, \\ Claudia Wosnitza-Mendo ${ }^{a}$, Juan Argüelles ${ }^{a}$, Sara Purca ${ }^{a}$, Patricia Ayón ${ }^{\text {a }}$, Luis Quipuzcoa ${ }^{\text {, }}$ \\ Dimitri Gutiérrez ${ }^{a}$, Elisa Goya ${ }^{a}$, Noemí Ochoa ${ }^{d}$, Matthias Wolff ${ }^{b}$ \\ anstituto del Mar del Perú (IMARPE), Apdo. 22, Callao, Peru \\ ${ }^{\mathrm{b}}$ Center for Tropical Marine Ecology, Fahrenheitstr. 6, 28359 Bremen, Germany \\ ' IRD, UR097, CRH, Avenue Jean Monnet, 34203 Sète, France \\ ${ }^{\mathrm{d}}$ Universidad Nacional Mayor de San Marcos, Apdo. 12, Lima, Peru
}

\section{A R T I C L E I N F O}

\section{Article history:}

Accepted 14 October 2008

Available online 21 October 2008

\section{Keywords:}

Ecotrophic model

Network analysis

El Niño

Peru

Humboldt Current

Trophic energy flow

Upwelling

\begin{abstract}
A B S T R A C T
The El Niño of 1997-98 was one of the strongest warming events of the past century; among many other effects, it impacted phytoplankton along the Peruvian coast by changing species composition and reducing biomass. While responses of the main fish resources to this natural perturbation are relatively well known, understanding the ecosystem response as a whole requires an ecotrophic multispecies approach. In this work, we construct trophic models of the Northern Humboldt Current Ecosystem (NHCE) and compare the La Niña (LN) years in 1995-96 with the El Niño (EN) years in 1997-98. The model area extends from $4^{\circ} \mathrm{S}-16^{\circ} \mathrm{S}$ and to $60 \mathrm{~nm}$ from the coast. The model consists of 32 functional groups of organisms and differs from previous trophic models of the Peruvian system through: (i) division of plankton into size classes to account for EN-associated changes and feeding preferences of small pelagic fish, (ii) increased division of demersal groups and separation of life history stages of hake, (iii) inclusion of mesopelagic fish, and (iv) incorporation of the jumbo squid (Dosidicus gigas), which became abundant following EN. Results show that EN reduced the size and organization of energy flows of the NHCE, but the overall functioning (proportion of energy flows used for respiration, consumption by predators, detritus and export) of the ecosystem was maintained. The reduction of diatom biomass during EN forced omnivorous planktivorous fish to switch to a more zooplankton-dominated diet, raising their trophic level. Consequently, in the EN model the trophic level increased for several predatory groups (mackerel, other large pelagics, sea birds, pinnipeds) and for fishery catch. A high modeled biomass of macrozooplankton was needed to balance the consumption by planktivores, especially during EN condition when observed diatoms biomass diminished dramatically. Despite overall lower planktivorous fish catches, the higher primary production required-to-catch ratio implied a stronger ecological impact of the fishery and stresses the need for precautionary management of fisheries during and after EN. During EN energetic indicators such as the lower primary production/total biomass ratio suggest a more energetically efficient ecosystem, while reduced network indicators such as the cycling index and relative ascendency indicate of a less organized state of the ecosystem. Compared to previous trophic models of the NHCE we observed: (i) a shrinking of ecosystem size in term of energy flows, (ii) slight changes in overall functioning (proportion of energy flows used for respiration, consumption by predators and detritus), and (iii) the use of alternate pathways leading to a higher ecological impact of the fishery for planktivorous fish.
\end{abstract}

(c) 2008 Elsevier Ltd. All rights reserved.

\section{Introduction}

The northern part of the Humboldt Current Ecosystem (HCE) off Peru has been modelled with carbon and nitrogen budget models (Dugdale and MacIsaac, 1971; Walsh and Dugdale, 1971; Walsh,

\footnotetext{
* Corresponding author.

E-mail address: jtam@imarpe.gob.pe (J. Tam).
}

1981), mass balance models (Jarre et al., 1989, 1991; Jarre and Pauly, 1993; Ballón, 2005), a size-based carbon flow model (Carr, 2003) and an empirical carbon flow model (Jahncke et al., 2004). Mass balance models have also been applied in the southern HCE off Chile (Wolff 1994; Ortiz and Wolff, 2002; Arancibia et al., 2003; Neira et al., 2004; Neira and Arancibia, 2004). These models have permitted comparisons between the HCE and other eastern boundary current ecosystems (Jarre, 1998; Jarre and Christensen, 
1998; Jarre et al., 1998; Moloney et al., 2005). However, none of these models have focused on the impact of the interannual variability associated with El Niño (EN).

According to Alheit and Niquen (2004), a regime shift occurred in Peruvian waters between 1968 and 1970, wherein waters warmed and zooplankton and anchovy (Engraulis ringens) biomass decreased, followed by an increase in sardine (Sardinops sagax) stocks. However, another regime shift back to cold conditions occurred during 1984-1986, in this case characterized by an increase of phytoplankton and zooplankton biomasses (see Ayon et al., 2008) associated with excellent recruitment of anchovy but decreases in sardine biomass.

Arntz and Fahrbach (1991) summarized the effects of the 198283 EN on the Northern Humbolt Current Ecosystem (NHCE). During $\mathrm{EN}$, in the NHCE near surface temperature increases and the thermocline deepens, causing a collapse of the diatom-based trophic web, with emigration of anchovy and immigration of tropical and oceanic species. Gutierrez (2001) and Bertrand et al. (2004) described the effects of the 1997-98 EN on anchovy distribution and abundance, confirming that anchovy move to deeper waters but finding that the main spatial effect was concentration of stocks very nearshore. These authors attribute an apparent reduction in anchovy biomass to decreased effectiveness of acoustic sampling, unfavorable environmental conditions, increase of natural mortality due to poor feeding conditions, and to a much lesser degree, to mortality due to predation and fishing. Bouchon et al. (2001) analysed the ichthyofauna fluctuations over an El Niño Southern Oscillation (ENSO) cycle and concluded that in cold years the pelagic community is characterized by a high productivity and a low diversity (abundant diatoms and anchovy), but in warm years this pattern is reversed due to the immigration of offshore and tropical species and the reduction of anchovy. While responses of the main fish resources to EN-related perturbations are relatively well known (Aguilar, 1999; Tarazona et al., 2001), understanding the ecosystem response as a whole requires a multispecies 'ecotrophic' approach. Given the observed changes in biomass and species composition, it is expected that a strong EN impacts the food web, reducing or redistributing the main energy channel that flows through anchovy under La Niña (LN) conditions.

Previous models of the NHCE (Jarre et al., 1991), which described the flow of energy through the ecosystem during three decades (1953-1959, 1960-1969, 1973-1979), brought great understanding of ecosystem functioning. Now however, biological changes, new data sets, and the advancement of trophodynamic modeling permit construction of more detailed models through the inclusion of additional 'functional groups' of organisms (see also Guenette et al., 2008). In this paper we divided the phytoplankton compartment into two groups (diatoms and dino- and silicoflagellates) and zooplankton into three groups (micro-, mesoand macro-zooplankton) to account for the feeding preferences of different small pelagic fish. We incorporated the groups of mesopelagic fish and jumbo squid (Dosidicus gigas), which have gained in importance since the last 1997-98 EN. We also increased the detail of demersal groups and separated the hake into three different life history stages. The ecotrophic model framework is a simplified approach where species are aggregated into functional groups. Each group is represented by two linear equations, each of which must balance. One equation ensures balance between groups in the model, the other equation, balances the flows within each group.

The objective of this study is to compare such improved mass balance trophic models for a cold LN conditions (1995-96) versus a warm EN (1997-98) conditions, with the a priori hypothesis that the EN perturbation should decrease ecosystem organization. This paper also provides the basis for further explorations of ecosystem dynamics (Taylor et al., this 2008a), wherein non-steady state sim- ulations of ecosystem change during and following the 1997-98 EN are performed and evaluated. In dynamic models, biomass changes are expressed in form of coupled differential equations derived from mass balance models equations.

\section{Methods}

\subsection{Input data}

Our models of the Northern Humboldt Current Ecosystem (NHCE) extend from $4^{\circ} \mathrm{S}$ to $16^{\circ} \mathrm{S}$, and $60 \mathrm{~nm}$ offshore, covering an area of approximately $165000 \mathrm{~km}^{2}$ (Fig. 1). In agreement with the ENSO cycle, data from June 1995 to May 1996 and from May 1997 to April 1998 were used as inputs for the cold LN and warm EN mass balance models, respectively, covering a full "biological year" each (i.e. starting from about the middle of a calendar year).

The models included 33 functional groups, namely: (1) diatoms, (2) dino- and silicoflagellates, (3) microzooplankton $(20-200 \mu \mathrm{m})$, (4) mesozooplankton $(200-2000 \mu \mathrm{m})$, (5) macrozooplankton (2$20 \mathrm{~mm}$ ), (6) gelatinous zooplankton, (7) macrobenthos, (8) sardine, (9) anchovy, (10) mesopelagics (Vinciguerria lucetia, Lampanyctus spp., Leuroglossus spp.), (11) jumbo squid, (12) other cephalopods (Loligo gahi, Octopus vulgaris, Logigunculla sp.), (13) other small pelagics (e.g. Anchoa nasus). (14) horse mackerel (Trachurus murphyi), (15) mackerel (Scomber japonicus), (16) other large pelagics (e.g. Sarda chiliensis, Coryphaena hippurus, Thunnus albacares), (17) small hake (Merluccius gayi peruanus, $<29 \mathrm{~cm}$ ), (18) medium hake (M. gayi peruanus, 30-49 $\mathrm{cm})$, (19) large hake (M. gayi peruanus, $>50 \mathrm{~cm}$ ), (20) flatfishes (Paralichthys adspersus., Hippoglosina sp.), (21) small demersals (e.g. Odonthestes regia, Labrisomus philippi, Ctenosciaena peruviana), (22) benthic elasmobranchs, (23) butter fishes (Trachinotus paitensis, Stromateus stellatus, Peprilus medius), (24) congers, (25) medium demersal fishes (e.g. Paralabrax humeralis, Hemanthias peruanus, Mugil cephalus), (26) medium sciaenids, (27) sea robin (Prionotus stephanophrys), (28) catfishes (Galeichtys

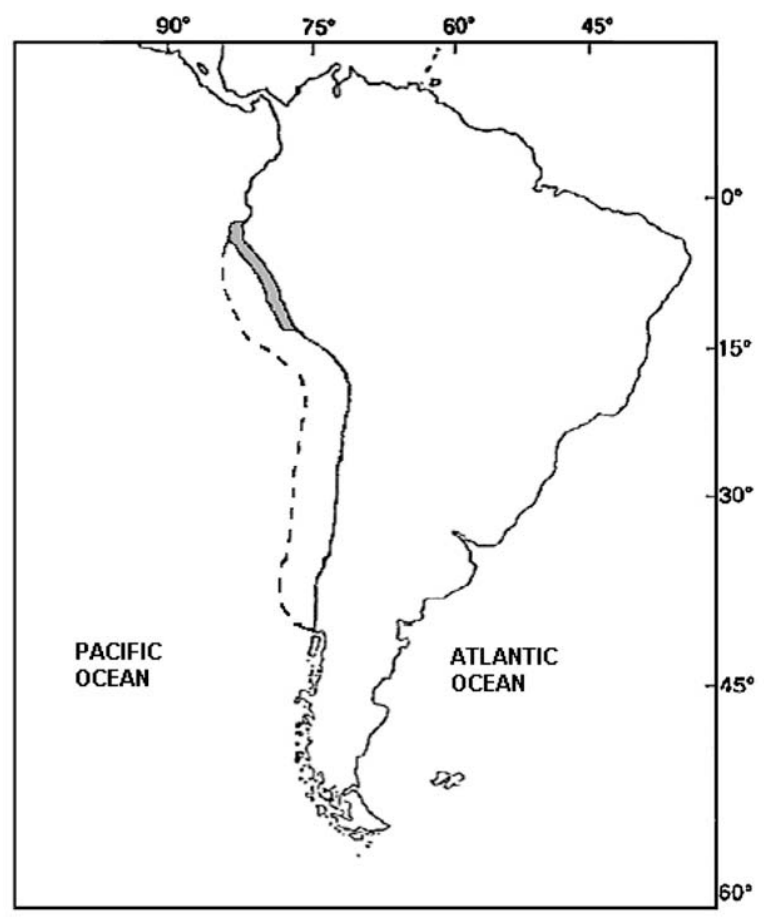

Fig. 1. Study area covers from $4^{\circ} \mathrm{S}$ to $16^{\circ} \mathrm{S}$, and up to $60 \mathrm{~nm}$ (grey shaded area), in the Northern Humboldt Current Ecosystem (dashed line) (modified from Alheit and Ñiquen, 2004). 
peruvianus), (29) chondrichthyans, (30) seabirds (Phalacrocorax bougainvillii, Sula variegata, Pelecanus thagus), (31) pinnipeds (Otaria flavescens, Arctocephalus australis), (32) cetaceans, and (33) detritus.

Models were constructed using the Ecopath software (Ecopath with Ecosim version 5.1; Christensen et al., 2005). Mass balance models are based on two equations for each functional group $i$ (Christensen and Pauly, 1992).

The energy balance equation

$Q_{i}=P_{i}+R_{i}+U F_{i}$

where $Q_{i}=$ prey consumption, $P_{i}=$ production, $R_{i}=$ respiration, $U F_{i}=$ unassimilated food (including excretion and egestion) and, the production components equation

$P_{i}=B_{i} * M 0_{i}+E X_{i}+B_{i} * M 2_{i}+B A_{i}$

where $M 0_{i}=$ non-predatory mortality (expressed as a function of ecotrophic efficiency, $E E_{i}$ ), $M 2_{i}$ = predatory mortality (expressed as a function of diet composition, $D C$ ), $\mathrm{EX}_{\mathrm{i}}=$ export (including catch $C_{i}$ and net migration, $\left.N M_{i}\right), B A_{i}=$ biomass accumulation. $E E_{i}$ is the proportion of the production that is utilized in the system and is defined as

$E E_{i}=\left(B_{i} * M 2_{i}+C_{i}+N M_{i}+B A_{i}\right) / P_{i}$

Thus, for each functional group, required input data is: wet weight biomass $\left(B, \mathrm{t} \mathrm{km}^{-2}\right)$, production/biomass ratio $\left(P / B, \mathrm{y}^{-1}\right)$, consumption/biomass ratio $\left(\mathrm{Q} / B, \mathrm{y}^{-1}\right)$, catch $\left(C, \mathrm{t} \mathrm{km}^{-2} \mathrm{y}^{-1}\right)$ and diet composition $(D C)$ for each functional group. One unknown parameter (either $B, P / B, Q / B$ or $E E$ ) can be estimated when solving the system of linear equations.

Input data for the models were gathered from published and unpublished sources (Table 1). Catch values were obtained from IMARPE (2006) landing statistics and the Sea Around Us (2006) database; some values of production/consumption ratio $(P / Q)$ and unassimilated food (UF) were obtained from Moloney et al. (2005). Sea surface phytoplankton biomass was calculated from relationships of upwelling area vs. chlorophyll $a$ (chl. a) threshold as calculated by Nixon and Thomas (2001). Conversion factors of carbon/chl. $a=40$ (Brush et al., 2002) and wet weight/carbon $=14.25$ (Brown et al., 1991) were used to estimate wet weights. Proportion of diatoms vs. silico- and dinoflagellates during LN and EN conditions were obtained from a time series (1992-2000) of species cell counts carried out by Universidad Nacional Mayor de San Marcos UNMSM at Ancón Bay, Central Peru $\left(77^{\circ} 11^{\prime} \mathrm{W}-11^{\circ} 46^{\prime} \mathrm{S}\right)$. Phytoplankton cell counts were converted to biovolumes using the geometric formulas and software of Sun and Liu (2003); cell dimensions were obtained from the literature (e.g. Strickland et al., 1969; SERC, 2006; NODC, 2001) or measured under a microscope at the UNMSM. To convert biomass units from $\mathrm{m}^{3}$ to $\mathrm{m}^{2}$, a mixed layer depth of $40 \mathrm{~m}$ was estimated by averaging vertical profiles of chl. $a$ from several latitudes along the Peruvian coast with data from Calienes et al. (1985). Individual zooplankter body masses were estimated from abundance and biomass data (Ayón and Arones, 1997a,b) and zooplankter biovolumes were calculated from individual counts by taxonomic group using length:weight relationships from Rippe (1996) with body dimensions obtained from Santander et al. (1981) and Wangelin and Wolff (1996). Such biovolume conversions were also needed to convert stomach content data for sardine and anchovy (numbers of phytoplankton cells and zooplankton individuals per stomach by species) into fractions by weight.

In an Ecopath model, the Pedigree Index $(P)$ permits assignment of quality or confidence ratings to each parameter. Qualitative pedigree index values were assigned as in Table 2 . Based on the individual index values $\left(I_{i j}\right)$ an overall Pedigree Index $(P)$ is calculated using
$P=\sum_{i=1}^{n} \frac{I_{i j}}{n}$

where $I_{i j}$ is the pedigree index value for group $i$ and parameter $j$ for each of the $n$ living groups in the ecosystem. For the models constructed here, $P$ was 0.638 ( $P$ scales between 0 and $1 ; t^{*}=4.54$, $n=32, p<0.001$ ), indicating good model quality with parameters mostly based on local data. For comparison, of 50 Ecopath models reviewed by Morissette (2007), only four models had higher pedigree indices than the present study (upper 7.5\%).

Conservative estimates of biomass of some groups were calculated by the software assuming an ecotrophic efficiency of 0.95 (microzooplankton, macrozooplankton, gelatinous zooplankton, small pelagics, small demersals and other cephalopods). Ecotrophic efficiency $(0<E E<1)$ and gross efficiency $(0<G E<0.4)$ served as constraints for balancing the models. Gross food conversion efficiency is estimated using

$G E_{i}=\left(P_{i} / B_{i}\right) /\left(Q_{i} / B_{i}\right)$

Energy flow balance of models was achieved by tuning the diets of some groups. The dietary composition for functional groups is presented in Table 3. Based on the input data, the Ecopath software calculated ecosystem indicators which describe the state of an ecosystem in terms of energy flows. Behavior of trophic, fishery, energetic and network ecosystem indicators have been related to theories of ecosystem maturity (Odum, 1969) and health (Ulanowicz, 1997) (see Table 4 for a description). The trophic level of a group $(T L)$ is calculated as the mean trophic level of its prey plus 1 , assuming that primary producers and detritus groups have a trophic level of 1.0. Thus, trophic level is calculated using

$T L_{j}=1+\sum\left(T L_{i}\right)\left(D C_{i j}\right)$

where $D C_{i j}$ is the fraction of prey $i$ in the diet of the predator $j$.

The transfer efficiency (TE) of each discrete trophic level is defined as a measure of the fraction of input to each of the aggregated trophic levels that is passed on to the next level, that is, the fraction that is either consumed by predators or harvested

$T E_{n}=\left(Q_{n+1}+E X_{n}\right) / Q_{n}$

where $n$ is the trophic level.

\section{Results and discussion}

\subsection{Biomass and catch changes}

Tables $5 \mathrm{~A}$ and $\mathrm{B}$ presents results for LN and EN conditions, respectively. The model synthesizes available data and estimates additional parameters (bold type in Table 5) that define the relationships between the functional groups of organisms in the model. During the LN conditions diatoms, mesozooplankton, anchovy, horse mackerel, mackerel and jumbo squid dominated in biomass in their respective trophic levels. During EN conditions, biomasses of most groups decreased (anchovy, jumbo squid, horse mackerel, hake, demersal fishes, seabirds and pinnipeds), mainly due to a bottom-up control originating from biomass reduction in the lower trophic levels (diatoms, micro- and mesozooplankton). During EN conditions, macrobenthos biomass increased, mainly in the central zone off Peru $\left(10-15^{\circ} \mathrm{S}\right.$; Quipuzcoa et al., 2001), probably because bottom oxygen concentrations increased, improving conditions for many organisms. However, biomasses of demersal fish species decreased (e.g. hake, small demersals).

Biomasses of some groups increased during EN (Fig. 2), possibly being favored by low nutrient conditions or higher temperatures (dinoflagellates, macrozooplankton) and/or immigration of some fish (mesopelagics, small pelagics, large pelagics and 
Table 1

Input data for the models of the NHCE and their sources. Biomass $(B)$, production $(P)$, consumption $(Q)$ and catch $(C)$

\begin{tabular}{|c|c|c|c|c|c|c|c|c|}
\hline $\begin{array}{l}\text { Functional group } \\
\text { Period }\end{array}$ & $\begin{array}{l}B \\
1995-96 \\
\end{array}$ & 1997-98 & $\begin{array}{l}P / B \\
1995-96 \\
\end{array}$ & 1997-98 & $\begin{array}{l}Q / B \\
1995-98 \\
\end{array}$ & $\begin{array}{l}C \\
1995-96 \\
\end{array}$ & 1997-98 & Source \\
\hline 1. Diatoms & 53.416 & 14.761 & 265 & 210 & & & & $\begin{array}{l}\text { B, P/B calculated from Nixon and Thomas (2001) curve, } 85 \% \text { (1995-96) and } 46 \% \\
\text { (1997-98) of diatoms calculated from Ancon, Central Peru (Ochoa, personal } \\
\text { communication) and Sanchez (1996) data converted to biovolumes. }\end{array}$ \\
\hline 2. Silico- and dinoflagellates & 9.426 & 17.328 & 265 & 210 & & & & $\begin{array}{l}B, P / B \text { calculated from Nixon and Thomas (2001) curve, } 15 \% \text { (1995-96) and } 86 \% \\
\text { (1997-98) of silico- and dinoflagellates calculated from data converted to } \\
\text { biovolumes from Ancon, Central Peru (Ochoa, personal communication) and Sanchez } \\
\text { (1996). }\end{array}$ \\
\hline 3. Microzooplankton (20-200 um) & & & 256 & 256 & & & & $P / B$ from Sorokin and Kogelschatz (1979), diet from Shannon et al. (2003). \\
\hline 4. Mesozooplankton (200-2000 um) & 31.164 & 17 & 40 & 40 & & & & $\begin{array}{l}\text { B calculated from IMARPE data (Ayon, personal communication), } P / B \text { from Moloney } \\
\text { et al. (2005), diet from Shannon et al. (2003). }\end{array}$ \\
\hline 5. Macrozooplankton $(2-20 \mathrm{~mm})$ & & & & & 46.55 & & & Q/B from Antezana (2002a), diet from Shannon et al. (2003). \\
\hline 6. Gelatinous zooplankton & & & 0.584 & 0.584 & & & & $P / B$ from Jarre et al. (1998), diet from Shannon et al. (2003). \\
\hline 7. Macrobenthos & 20.729 & 25.605 & 1.2 & 1.2 & 10 & & & $\begin{array}{l}\text { B calculated from IMARPE data (Gutierrez and Quipuzcoa, personal communication), } \\
P / B \text { and } Q / B \text { from Walsh (1981) in Jarre et al. (1989), diet from Shannon and Jarre } \\
\text { (1999). }\end{array}$ \\
\hline 8. Sardine (Sardinops sagax) & 7.567 & 7.909 & 1.4 & 1.4 & & 7.97 & 3.33 & $\begin{array}{l}\text { B calculated from IMARPE acoustic data (Gutierrez, personal communication), } P / B \\
\text { from Patterson et al. (1992), diet calculated from Alamo et al. (1996a, 1996b), Alamo } \\
\text { et al. (1997a, 1997b), Alamo and Espinoza (1998), Blaskovic et al. (1998), Espinoza } \\
\text { et al. (1998a, 1998b), Blaskovic et al. (1999). }\end{array}$ \\
\hline 9. Anchovy (Engraulis ringens) & 83.293 & 33.34 & 2 & 2 & & 30.47 & 14.48 & $\begin{array}{l}\text { B from IMARPE VPA (Ñiquen, personal communication), } P / B \text { from Csirke et al. (1996), } \\
\text { diet calculated from Alamo et al. (1996a, 1996b), Alamo et al. (1997a, 1997b), Alamo } \\
\text { and Espinoza (1998), Blaskovic et al. (1998), Espinoza et al. (1998a, 1998b), Blaskovic } \\
\text { et al. (1999). }\end{array}$ \\
\hline 10. Mesopelagics & 6.882 & 22.375 & 1.4 & 1.4 & & & & $\begin{array}{l}\text { B calculated from relationship between Vinciguerria lucetia and Dosidicus gigas from } \\
\text { IMARPE acoustic data 1999-2005 (Gutierrez, personal communication), } P / B \\
\text { calculated from maximum age, diet calculated from IMARPE data (Blaskovic, } \\
\text { personal communication) }\end{array}$ \\
\hline 11. Jumbo squid (Dosidicus gigas) & 0.524 & 0.243 & 8.91 & 8.91 & & 0.19 & 0.01 & $\begin{array}{l}\text { B calculated from relationship between CPUE and B of Dosidicus gigas from IMARPE } \\
\text { acoustic data 1999-2005 (Gutierrez, personal communication), P/B from Alegre et al. } \\
\text { (2005), diet calculated from IMARPE industrial fleet data (Blaskovic, personal } \\
\text { communication), Schetinnikov (1989), Nigmatullin et al. (2001). }\end{array}$ \\
\hline 12. Other Cephalopods & & & 4.3 & 4.3 & & 0.05 & 0.01 & $\begin{array}{l}P / B \text { from IMARPE VPA (Arguelles, personal communication), diet from Cardoso et al. } \\
\text { (1998) and Villegas (2001). }\end{array}$ \\
\hline 13. Other small pelagics & & & 1 & 1 & & 0.69 & 2.36 & $\begin{array}{l}\text { P/B from Shannon et al. (2003) for saury (Scomberesox saurus), flying fish } \\
\text { (Exocoetidae), pelagic goby (Sufflogobius bibarbatus), diet based on Jarre et al. (1989). }\end{array}$ \\
\hline 14. Horse mackerel (Trachurus murphyi) & 11.568 & 3.03 & 1.2 & 1.2 & & 1.45 & 1.94 & $\begin{array}{l}\text { B from IMARPE acoustic data (Gutierrez, personal communication), } P / B \text { from } \\
\text { Moloney (2005), diet calculated from IMARPE data (Blaskovic, personal } \\
\text { communication) }\end{array}$ \\
\hline 15. Mackerel (Scomber japonicus) & 8.488 & 6.892 & 0.85 & 0.85 & & 0.10 & 1.34 & $\begin{array}{l}\text { B from IMARPE acoustic data (Gutierrez, personal communication), } P / B \text { from Jarre } \\
\text { et al. (1989), diet calculated from IMARPE data (Blaskovic, personal communication) }\end{array}$ \\
\hline 16. Other large pelagics & 0.589 & 1.757 & 0.85 & 0.4 & & 0.25 & 0.35 & $\begin{array}{l}\text { B calculated from catch equal to } 50 \% \text { production, } P / B \text { from Jarre et al. (1989), diet } \\
\text { calculated from IMARPE data (Blaskovic, personal communication) } \\
\text { (continued on next page) }\end{array}$ \\
\hline
\end{tabular}




\begin{tabular}{|c|c|c|c|c|c|c|c|c|}
\hline Functional group & $B$ & & $P / B$ & & $\mathrm{Q} / \mathrm{B}$ & $C$ & & Source \\
\hline $\begin{array}{l}\text { 17. Small hake (Merluccius } \\
\text { gayi peruanus, }<29 \mathrm{~cm} \text { ) }\end{array}$ & 2.771 & 1.245 & 0.928 & 1.317 & & 0.97 & 0.56 & $\begin{array}{l}\text { B from IMARPE VPA (Wosnitza, personal communication), } P / B \text { calculated as average } \\
\text { of } Z \text { from VPA of the age groups involved (Ballon, personal communication), diet } \\
\text { calculated from IMARPE data (Blaskovic, personal communication). }\end{array}$ \\
\hline $\begin{array}{l}\text { 18. Medium hake (M. gayi } \\
\text { peruanus, } 30-49 \mathrm{~cm} \text { ) }\end{array}$ & 0.414 & 0.163 & 1.627 & 1.946 & & 0.22 & 0.11 & $\begin{array}{l}\text { B from IMARPE VPA (Wosnitza, personal communication), } P / B \text { calculated as average } \\
\text { of } Z \text { from VPA of the age groups involved (Ballon, personal communication), diet } \\
\text { calculated from IMARPE data (Blaskovic, personal communication). }\end{array}$ \\
\hline $\begin{array}{l}\text { 19. Large hake (M. gayi } \\
\text { peruanus, }>50 \mathrm{~cm} \text { ) }\end{array}$ & 0.055 & 0.028 & 1.044 & 1.516 & & 0.02 & 0.01 & $\begin{array}{l}\text { B from IMARPE VPA (Wosnitza, personal communication), } P / B \text { calculated as average } \\
\text { of } Z \text { from VPA of the age groups involved (Ballon, personal communication), diet } \\
\text { calculated from IMARPE data (Blaskovic, personal communication) }\end{array}$ \\
\hline 20. Flatfishes & 0.04 & 0.01 & 0.304 & 0.304 & & 0.01 & 0.00 & $\begin{array}{l}\text { B from swept area data corrected with hake VPA (Wosnitza, personal } \\
\text { communication), } P / B \text { from Neira et al. (2004), diet calculated from IMARPE data } \\
\text { (Blaskovic, personal communicaiton) }\end{array}$ \\
\hline 21. Small demersals & & & 2.3 & 2.3 & & 0.02 & 0.02 & $\begin{array}{l}\text { B from swept area data corrected with hake VPA (Wosnitza, personal } \\
\text { communicaiton), } P / B \text { from Wolff et al. (1998), diet calculated from IMARPE data } \\
\text { (Blaskovic, personal communication) }\end{array}$ \\
\hline 22. Benthic elasmobranchs & 0.078 & 0.045 & 1 & 1 & & 0.03 & 0.04 & $\begin{array}{l}\text { B from swept area data corrected with hake VPA (Wosnitza, personal } \\
\text { communication), } P / B \text { based on Shannon et al. (2003), diet calculated from IMARPE } \\
\text { data (Blaskovic, personal communication) }\end{array}$ \\
\hline 23. Butter fishes & 0.032 & 0.006 & 0.8 & 0.8 & & & & $\begin{array}{l}\text { B from swept area data corrected with hake VPA (Wosnitza, personal } \\
\text { communication), } P / B \text { from Wolff et al. (1998), diet calculated from IMARPE data } \\
\text { (Blaskovic, personal communication) }\end{array}$ \\
\hline 24. Conger & 0.019 & 0.004 & 0.75 & 0.75 & & & & $\begin{array}{l}\text { B from swept area data corrected with hake VPA (Wosnitza personal } \\
\text { communicaiton), } P / B \text { from Wolff et al. (1998), diet calculated from IMARPE data } \\
\text { (Blaskovic, personal communication) }\end{array}$ \\
\hline 25. Medium demersal fish & 0.2 & 0.211 & 1.32 & 2.48 & & 0.13 & 0.14 & $\begin{array}{l}\text { B from swept area data corrected with hake VPA (Wosnitza, personal } \\
\text { communication), } P / B \text { calculated from catch curve for Paralabrax humeralis (Ballon, } \\
\text { personal communication), diet calculated from IMARPE data (Blaskovic, personal } \\
\text { communication) }\end{array}$ \\
\hline 26. Medium sciaenids & 0.369 & 0.218 & 0.746 & 1.085 & & 0.07 & 0.04 & $\begin{array}{l}\text { B from swept area data corrected with hake VPA (Wosnitza, personal } \\
\text { communication), } P / B \text { calculated from catch curve for Cynoscion analis (Ballon, } \\
\text { personal communicaiton), diet calculated from IMARPE data (Blaskovic, personal } \\
\text { communication) }\end{array}$ \\
\hline $\begin{array}{l}\text { 27. Sea robin (Prionotus } \\
\text { stephanophrys) }\end{array}$ & 0.789 & 0.319 & 3.4 & 3.22 & & & & $\begin{array}{l}\text { B from swept area data corrected with hake VPA (Wosnitza, personal } \\
\text { communication), P/B calculated from catch curve (Ballon, personal communication), } \\
\text { diet calculated from IMARPE data (Blaskovic, personal communication) }\end{array}$ \\
\hline 28. Catfish & 0.577 & 0.65 & 0.9 & 0.9 & & 0.07 & 0.54 & $\begin{array}{l}\text { B from swept area data corrected with hake VPA (Wosnitza, personal } \\
\text { communication), } P / B \text { from Wolff et al. (1998), diet calculated from IMARPE data } \\
\text { (Blaskovic, personal communication) }\end{array}$ \\
\hline 29. Chondrichthyans & 0.027 & 0.078 & 0.486 & 0.486 & & 0.01 & 0.02 & $\begin{array}{l}\text { B calculated from catch equal to } 50 \% \text { production, } P / B \text { calculated from Frisk et al. } \\
\text { (2001) and Au and Smith (1997), diet calculated from IMARPE data (Blaskovic, } \\
\text { personal communicaiton). }\end{array}$ \\
\hline 30. Seabirds & 0.067 & 0.01 & 0.04 & 0.04 & 60 & & & $\begin{array}{l}\text { B from IMARPE abundance data converted to biomass (Goya, personal } \\
\text { communicaiton), } P / B \text { and } Q / B \text { from Jarre et al. (1989), diet from Guillen (1990). }\end{array}$ \\
\hline 31. Pinnipeds & 0.072 & 0.053 & 0.1 & 0.1 & 45.9 & & & $\begin{array}{l}\text { B from IMARPE abundance data converted to biomass (Goya, personal } \\
\text { communicaiton), } P / B \text { from Jarre et al. (1989), Q/B from Muck and Fuentes (1987) in } \\
\text { Jarre et al. (1989), diet from Arias (2003). }\end{array}$ \\
\hline 32. Cetaceans & 0.062 & 0.067 & 0.1 & 0.1 & 20 & & & $\begin{array}{l}\text { B calculated from modelled biomass of mysticetes, small and large odontocetes } \\
\text { (Kaschner 2004), } 1.1 \text { sightings ratio 1997/1995 calculated from Bello et al. (1998). } \\
\text { Q/B from Moloney et al. (2005), diet based on Jarre et al. (1998). }\end{array}$ \\
\hline
\end{tabular}


Table 2

Pedigree index values qualitatively assigned to model parameters. Biomass $(B)$, production $(P)$, consumption $(Q)$, diet composition $(D C)$ and catch $(C)$. Lower pedigree index values correspond to guesstimates or other models, while higher pedigree index values correspond to high precision estimates locally based.

\begin{tabular}{llllll}
\hline Functional group & $B$ & $P / B$ & $Q / B$ & $D C$ & $C$ \\
\hline 1. Diatoms & 0.7 & 0.5 & & & \\
2. Dino- and silicoflagellates & 0.7 & 0.5 & & & \\
3. Microzooplankton & 0 & 0.6 & 0.6 & 0.2 & \\
4. Mesozooplankton & 0.7 & 0.6 & 0.6 & 0.2 & \\
5. Macrozooplankton & 0.7 & 0.6 & 0.6 & 0.2 & \\
6. Gelatinous zooplankton & 0 & 0.2 & 0.6 & 0.2 & \\
7. Macrobenthos & 0.7 & 0.2 & 0.6 & 0.2 & \\
8. Sardine & 0.4 & 1 & 0.6 & 1 & 1 \\
9. Anchovy & 0.4 & 1 & 0.6 & 1 & 1 \\
10. Mesopelagics & 0.4 & 0.1 & 0.6 & 0.2 & \\
11. Jumbo squid & 0.4 & 1 & 0.6 & 0.5 & 1 \\
12. Other Cephalopods & 0.4 & 0.7 & 0.6 & 0 & 1 \\
13. Other small pelagics & 0 & 0.7 & 0.6 & 0 & 1 \\
14. Horse mackerel & 1 & 0.7 & 0.6 & 0.5 & 1 \\
15. Mackerel & 1 & 0.7 & 1 & 0.5 & 1 \\
16. Other large pelagics & 1 & 0.7 & 0.6 & 0.5 & 1 \\
17. Small hake & 1 & 1 & 0.6 & 1 & 1 \\
18. Medium hake & 1 & 1 & 0.6 & 1 & 1 \\
19. Large hake & 1 & 1 & 0.6 & 1 & 1 \\
20. Flatfishes & 0.4 & 0.8 & 0.6 & 0.7 & 1 \\
21. Small demersals & 0.4 & 0.2 & 0.6 & 0 & \\
22. Benthic elasmobranchs & 0.4 & 0.2 & 0.6 & 0.7 & 1 \\
23. Butter fishes & 0.4 & 0.2 & 0.6 & 0.7 & \\
24. Conger & 0.4 & 0.6 & 0.6 & 0.7 & \\
25. Medium demersal fish & 0.4 & 0.8 & 0.6 & 0.7 & 1 \\
26. Medium sciaenids & 0.7 & 0.8 & 0.6 & 0.7 & 1 \\
27. Sea robin & 0.7 & 0.8 & 0.6 & 0.7 & \\
28. Catfish & 0.4 & 0.1 & 0.6 & 0.7 & 1 \\
29. Chondrichthyans & 0 & 0.5 & 0.6 & 0.7 & 1 \\
30. Seabirds & 1 & 1 & 0.6 & 1 & \\
31. Pinnipeds & 1 & 1 & 0.6 & 1 & \\
32. Cetaceans & 0.4 & 0.6 & 0.6 & 0 & \\
\hline & & & & & \\
& & & & & \\
& & & & & \\
\end{tabular}

chondrichthyans). During the 1997-98 EN, Delgado et al. (2001) found dinoflagellates (e.g. Ceratium breve, Ceratium praelongum), and Ayón et al. (1997) found fish larvae (e.g. Hoplunnis pacifica, Monolene maculipinna) south of their characteristic ranges, immigrating with the intrusion of warm water masses.

For fish, catch reductions accompanied biomass reductions (Fig. 3), with the exception of sustained high catch changes of mackerel and catfish during EN (whose fishing mortalities were quite low in the cold period). Total catches decreased $41 \%$ during EN and the ratio of total catch to biomass decreased 19\% (Table 6). A slope $<1.0$ in Fig. 3 indicates that biomass changes do not translate immediately or fully into catch changes. Future management measures, should consider that EN-related reduction of catches should be at least proportional to the reduction of biomasses, allowing the exploitation rate $(F / Z)$ to be maintained. The general biomass and catch reductions during EN can also be appreciated in the pyramids given in Fig. 4.

Separation of phytoplankton into two functional groups (diatoms and silico-dinoflagellates) permits description of alternate pathways and differential responses of consumers. The reduction of diatom biomass during EN forced remaining omnivorous planktivorous fishes (anchovy and other small pelagics) to prey more on zooplankton in the model, (increasing their trophic level). Espinoza and Bertrand (2008) found a higher fraction of zooplankton during EN than in 1996 in anchovy stomachs. Modelled TL of anchovy increased from 2.35 to 3.17 from LN to EN conditions (Table 5). Consequently, the TL of piscivorous groups (large pelagics, seabirds, pinnipeds) also increased. Anchovy biomass reduction left sardine consumption of diatoms and dinoflagellates to increase slightly during EN, possibly in compensation for the increased competition with remaining anchovy for zooplankton, and because sardines are more efficient removers of small particles than anchovy (van der Lingen et al., 2006).

IMARPE zooplankton sampling ( $300 \mu \mathrm{m}$ mesh size nets towed from 0 to $50 \mathrm{~m}$ depth) captures mainly mesozooplankton, while macrozooplankton, specifically euphausiids, are undersampled due to their deeper distribution. For this reason, biomass of macrozooplankton was estimated within the model, resulting in $21.1 \mathrm{t} \mathrm{km}^{-2}$ during 1995-96, and $34.8 \mathrm{t} \mathrm{km}^{-2}$ during 1997-98. These high estimates are nevertheless conservative given that they were back-calculated using an ecotrophic efficiency of 0.95. Back calculations must be taken with caution and should ultimately be complemented with dynamic approaches using Ecosim, preferably with long time series of functional groups biomasses, in order to better constrain the estimates (Guenette et al., 2008; Taylor et al., 2008a). Nevertheless, the existence of such a high macrozooplankton biomass is supported by Antezana (2002a) who described Euphausia mucronata with SHCE biomass values up to $500 \mathrm{~g}$ wet weight per $1000 \mathrm{~m}^{3}$ within the oxygen minimum layer (Antezana, 2002b). Neira et al. (2004) also estimated high biomasses of euphausiids to meet the consumption requirements of model predators. Their estimates ranged from 73.6 to $106.3 \mathrm{t} \mathrm{km}^{-2}$ off central Chile. Moreover, the temporal variation of the diet of anchovy reported by Espinoza and Bertrand (2008) emphasized the importance of zooplankton over phytoplankton. All these evidences point to a high biomass of macrozooplankton in the NHCE as a prey of several species, especially during EN conditions when diatoms biomass diminishes. The apparent paradox of a high macrozooplankton biomass during EN conditions despite low phytoplankton biomass is explained by the lower consumption of diatoms by anchovy, leaving remaining phytoplankton for other species.

\subsection{Trophic flows}

A comparison of ecosystem indicators of both models (1995-96 and 1997-98) is presented in Table 6. According to Ulanowicz (1997), the 'size' of an ecosystem can be measured by its total activity in terms of energy flows, or by the total system throughput. In addition to the total biomass reduction $(-26.7 \%)$, total system throughput reduced dramatically $(-58.7 \%)$, along with a reduction of absolute energy flows for prey consumption, exports, respiration and to detritus. This reduction in the size of the modelled ecosystem in terms of total energy flows during EN is well-reflected in the energy flow pyramids (Fig. 4), where the volume of each compartment representing a trophic level is proportional to the total throughput of that level, and the top angle of the pyramids was made inversely proportional to the geometric mean of the transfer efficiencies between trophic levels.

A large decrease in total primary production during EN $(-59.5 \%)$ exerted a bottom-up control and decreased ecosystem "size" or total system throughput in the model. During EN the percentage contributions of total system throughput (Table 6) shows slight changes, on one hand an increase in consumption, and on the other hand a reduction in exports and flows into detritus. The relative reduction in exports and flows into detritus apparently reflects an increase in grazing by meso- and macro-zooplankton on phytoplankton in the model. These percentage flow changes were however small, indicating that although EN dramatically alters the system's absolute size, the relative flow of energy between functional groups seems largely unaltered.

While a comparison between ecotrophic models should ideally be based on a common model structure (Moloney et al., 2005), it is noteworthy that the total system throughput (ca. $60000 \mathrm{t} \mathrm{km}^{-2} \mathrm{y}^{-1}$ ) in the 1964-71 model before the anchovy collapse (Jarre et al., 1998) is similar to the value $\left(55689 \mathrm{t} \mathrm{km}^{-2} \mathrm{y}^{-1}\right.$ ) obtained here for the LN model. Total system throughput is rather 
Table 3

Diet composition of functional groups after the model was balanced, during LN (1995-96) and EN (1997-98). Values represent the fraction of the food intake in wet weight.

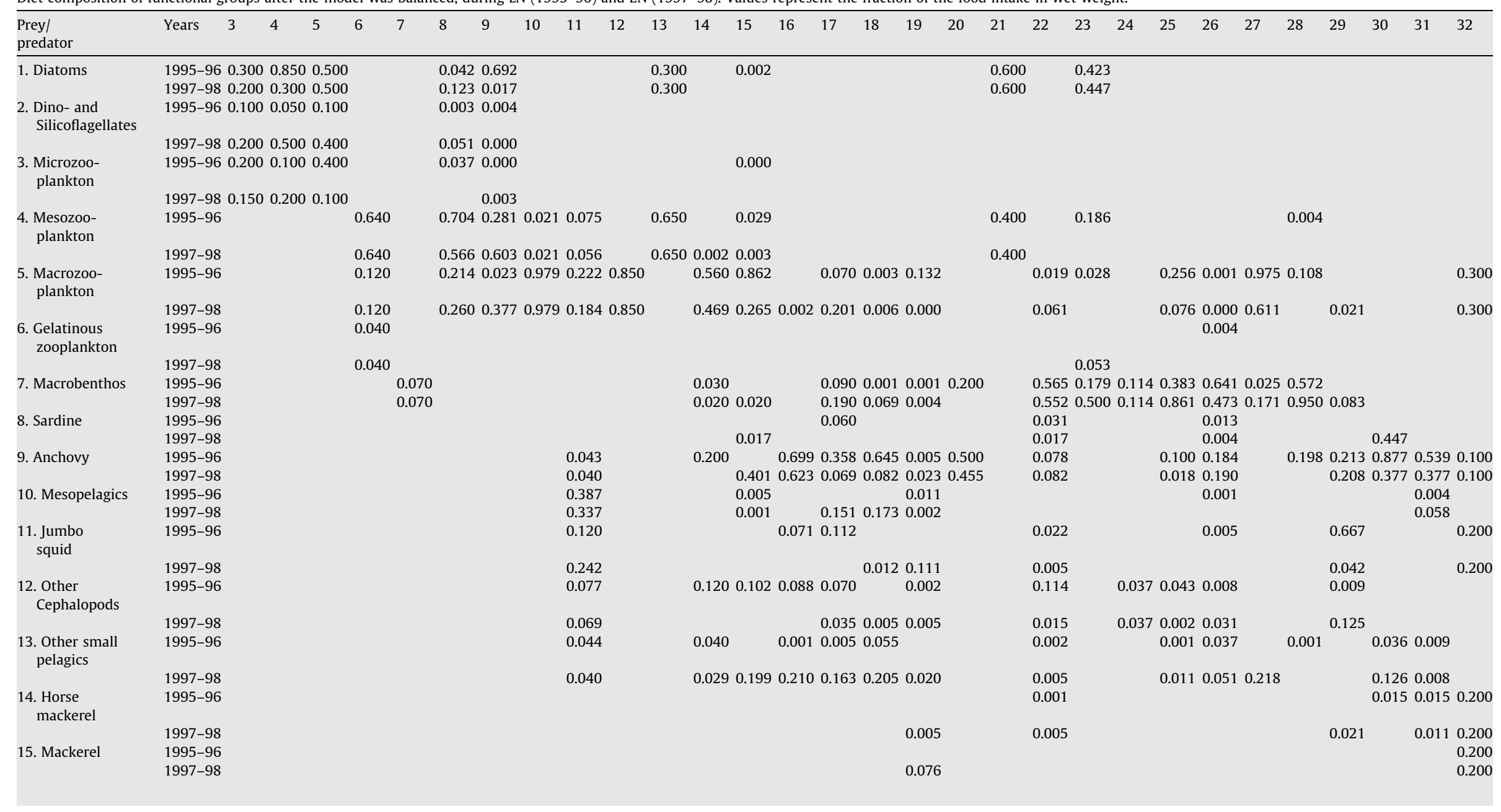




\begin{tabular}{|c|c|c|c|c|c|c|c|c|c|c|c|c|}
\hline \multirow[t]{2}{*}{$\begin{array}{l}\text { 16. Other large } \\
\text { pelagics }\end{array}$} & 1995-96 & & & & & & & & 0.001 & & & \\
\hline & 1997-98 & & & & 0.003 & & 0.005 & & 0.002 & & 0.374 & \\
\hline \multirow[t]{2}{*}{ 17. Small hake } & 1995-96 & & 0.032 & & & 0.386 & & & & & 0.099 & 0.013 \\
\hline & $1997-98$ & & 0.032 & & 0.0160 .147 & 0.406 & & & & & 0.058 & 0.050 \\
\hline \multirow{2}{*}{$\begin{array}{l}\text { 18. Medium } \\
\text { hake }\end{array}$} & 1995-96 & & & & & & 0.049 & 0.218 & & & 0.011 & \\
\hline & 1997-98 & & & & & & & 0.216 & & & 0.004 & \\
\hline \multirow[t]{2}{*}{ 19. Large hake } & 1995-96 & & & & & & & & & & 0.001 & \\
\hline & 1997-98 & & & & & & & & & & 0.001 & \\
\hline \multirow[t]{2}{*}{ 20. Flatfishes } & 1995-96 & & & & & & 0.002 & 0.0090 .001 & & & & \\
\hline & 1997-98 & & & & & & 0.005 & 0.009 & & & & \\
\hline \multirow{2}{*}{$\begin{array}{l}\text { 21. Small } \\
\text { demersals }\end{array}$} & 1995-96 & & 0.050 & $0.040 \quad 0.000 \quad 0.141$ & 0.1650 .046 & 0.115 & 0.099 & 0.0310 .186 & 0.031 & & 0.072 & 0.410 \\
\hline & 1997-98 & & 0.050 & $\begin{array}{llll}0.001 & 0.093 & 0.165\end{array}$ & 0.1500 .289 & 0.069 & 0.117 & 0.0310 .030 & 0.200 & & 0.0210 .050 & 0.471 \\
\hline \multirow{2}{*}{$\begin{array}{l}\text { 22. Benthic } \\
\text { elasmobranchs }\end{array}$} & 1995-96 & & & & & & & & & & & \\
\hline & $1997-98$ & & & & & & & & & & & \\
\hline \multirow{2}{*}{ 23. Butter fish } & $1995-96$ & & & & & & & & 0.001 & & & \\
\hline & 1997-98 & & & & & & 0.003 & & 0.002 & & & \\
\hline \multirow[t]{2}{*}{ 24. Conger } & 1995-96 & & & & & 0.030 & 0.000 & & & & & \\
\hline & 1997-98 & & & & & & & & & & & \\
\hline \multirow{2}{*}{$\begin{array}{l}\text { 25. Medium } \\
\text { demersal fish }\end{array}$} & 1995-96 & & & & & 0.300 & 0.009 & 0.3240 .030 & 0.003 & & & 0.006 \\
\hline & 1997-98 & & & & $0.020 \quad 0.001$ & 0.0140 .545 & 0.040 & 0.3260 .002 & 0.017 & & 0.021 & 0.015 \\
\hline \multirow{2}{*}{$\begin{array}{l}\text { 26. Medium } \\
\text { sciaenids }\end{array}$} & 1995-96 & & & & & 0.159 & 0.007 & 0.0200 .002 & 0.050 & & & 0.004 \\
\hline & 1997-98 & & & & $0.002 \quad 0.011$ & 0.241 & 0.029 & & 0.030 & & & 0.010 \\
\hline \multirow[t]{2}{*}{ 27. Sea robin } & 1995-96 & & & & $0.070 \quad 0.250$ & 0.159 & & 0.233 & & & & \\
\hline & 1997-98 & & & 0.001 & & 0.024 & & 0.233 & & & 0.021 & \\
\hline \multirow[t]{2}{*}{ 28. Catfish } & $1995-96$ & & & & & & 0.002 & & & 0.114 & & \\
\hline & 1997-98 & & & & & & 0.014 & & & & & \\
\hline \multirow[t]{2}{*}{$\begin{array}{l}\text { 29. Chondri- } \\
\text { chthyans }\end{array}$} & 1995-96 & & & & & & & & & & & \\
\hline & $1997-98$ & & & & & & & & & & & \\
\hline \multirow[t]{2}{*}{ 30. Seabirds } & $1995-96$ & & & & & & & & & & & \\
\hline & $1997-98$ & & & & & & & & & & & \\
\hline \multirow[t]{2}{*}{ 31. Pinnipeds } & 1995-96 & & & & & & & & & & & \\
\hline & 1997-98 & & & & & & & & & & & \\
\hline \multirow[t]{2}{*}{ 32. Cetaceans } & 1995-96 & & & & & & & & & & & \\
\hline & $1997-98$ & & & & & & & & & & & \\
\hline \multirow[t]{2}{*}{ 33. Detritus } & $1995-960.400$ & 0.2000 .800 & & 0.010 & & & & 0.1840 .034 & 0.021 & 0.003 & & \\
\hline & $1997-98 \quad 0.450$ & $0.200 \quad 0.800$ & & 0.479 & & & 0.045 & 0.034 & & 0.050 & & \\
\hline \multirow[t]{2}{*}{ Import } & $1995-96$ & 0.130 & $0.100 \quad 0.050$ & & & & & & & & & \\
\hline & 1997-98 & 0.130 & $0.100 \quad 0.050$ & & & & & & & & & \\
\hline
\end{tabular}


Table 4

Ecosystem indicators and their definitions.

\begin{tabular}{|c|c|}
\hline Ecosystem indicator & Definition (Christensen et al. 2005) \\
\hline \multicolumn{2}{|l|}{ Trophic indicators } \\
\hline Total system throughput & Sum of all flows in a system, represents the size of the system in terms of flows \\
\hline Total net primary production & $\begin{array}{l}\text { Summed production from all primary producers. Primary producers are groups that capture energy through photosynthesis } \\
\text { (e.g. phytoplankton and benthic algae) }\end{array}$ \\
\hline Mean transfer efficiency & Geometric mean of transfer efficiencies for trophic levels II-IV \\
\hline Connectance index & Ratio of the number of actual links to the number of possible links. It can be expected to be correlated with maturity \\
\hline Mixed trophic impact & $\begin{array}{l}\text { Combined direct and indirect trophic impacts that an infinitesimal increase of any of the groups is predicted to have on the } \\
\text { other groups of the ecosystem }\end{array}$ \\
\hline \multicolumn{2}{|l|}{ Fishery indicators } \\
\hline Mean trophic level of the catch & Sum of trophic levels of species in the catch weighted by their contribution to the catch \\
\hline Gross efficiency of the fishery & The sum of all realized fisheries catches relative to the total net primary production \\
\hline $\begin{array}{l}\text { Primary production required to sustain } \\
\text { catches (PPR) }\end{array}$ & $\begin{array}{l}\text { Flows in each path towards the catch of a group are converted to primary production equivalents using the product of catch, } \\
\text { production/consumption and the proportion of each group in the path in the diets of the other groups }\end{array}$ \\
\hline \multicolumn{2}{|l|}{ Energetic indicators } \\
\hline System primary production/respiration & Ratio between total primary production and total respiration. In mature systems, the ratio should approach 1 \\
\hline System primary production/biomass & Ratio between total primary production and total biomass. In mature systems, the ratio should decline \\
\hline System biomass/throughput & Ratio between total biomass and total system throughput. In mature systems, the ratio should increase \\
\hline \multicolumn{2}{|l|}{ Network indicators } \\
\hline Finn's cycling index & Fraction of an ecosystem's throughput that is recycled \\
\hline Relative ascendency & Ratio between ascendency and developmental capacity, a measure of ecosystem network efficiency (organization) \\
\hline
\end{tabular}

insensitive to changes in trophic web topology, but is strongly affected by energy flow changes.

Analysis of modeled prey consumption rates of predators (not shown) showed that horse mackerel, mackerel, hake and seabirds, consumed $28 \%$ and $46 \%$ of anchovy production during LN and EN conditions, respectively. Medium hake mainly preyed upon anchovy, sea robin, small pelagics and small demersals, while jumbo squid preyed upon mesopelagics and macrozooplankton.

Transfer efficiencies during LN conditions were similar as for other upwelling systems with most transfer efficiencies under 10\% (Christensen and Pauly, 1995), except for a peak value at trophic level III (17\%) due to high utilization of anchovy production (Fig. 5). The slight reductions of transfer efficiencies at high trophic levels during the EN conditions could reflect bottom-up control effects of anchovy over pinnipeds and seabirds. Majluf (1989) mentioned that reductions in the availability of anchoveta cause fur seals have to take a wider range of prey. Tovar et al. (1987) concluded that a lack of food is the ultimate cause for the mass mortalities of seabirds, as for every EN there is a corresponding decline of guano bird numbers. In general, during EN there was an increased utilization of energy at lower levels, while higher trophic levels have similar transfer efficiencies.

Consumption of macrozooplankton increased by $65 \%$ during EN conditions, assuming it was the main prey group in both periods for mesopelagic fishes. During EN, several immigrants come from equatorial and oceanic waters, such as chondrichtyans, mesopelagics (lightfish and lanternfish), other small pelagics and other large pelagics, which could impact different trophic levels. Mesopelagic Vinciguerria sp. are known to move towards the coast during EN, providing prey for jumbo squid. The increasing trend of jumbo squid, after 1997-98 EN, occurred in parallel to an increase of mesopelagics, thus a possible bottom-up control of mesopelagics over jumbo squid was explored with dynamic simulations (Taylor et al., 2008a).

\subsection{Ecosystem indicators}

Percentage changes of modelled ecosystem indicators from LN to EN (Table 6) showed that the overall reduction in primary production during EN, produced coherent changes in trophic, fisheries, energetic and network indicators. Fishery indicators showed a reduction in catches, accompanied by lower catch/biomass ratio and pelagic catch/demersal catch ratio, but higher trophic level of the catch and primary production required/catch ratio. In the NHCE, the mean trophic level of the catch increased temporarily $(+19 \%)$ during EN, mainly due to the increase of anchovy trophic level and a higher proportion of other species in the catch (e.g. mackerel, horse mackerel and other large pelagics). When only demersal fishes are taken into account, trophic level of the catch decreased during EN (from 3.66 to 3.34). However, at a larger spatio-temporal scale, the mean trophic level of the catch showed a decreasing trend from 1980 to 1994 in the South Eastern Pacific (Pauly et al., 1998), suggesting a fishing down the food web process, probably due to the recovery of anchovy, the main target species at low trophic level. Primary production required to sustain the fishery is a function of the trophic level of the species that are caught, as more primary production is required to produce one tonne of a high-level trophic fish, than of a low-level trophic fish.

Thus, despite lower catches during EN (-41\%), the increased trophic level of target species resulted in a higher primary production required/catch (+39\%), which implies an ecologically costly fishery and stresses the need for precautionary management during and after EN.

Most energetic indicators (net system production, net primary production and primary production/biomass ratio) decreased during EN (Table 4), except the higher system biomass/throughput ratio, apparently indicating a more energetically efficient ecosystem (Odum, 1969) during EN. However, network indicators such as lower Finn's cycling index and relative ascendency indicated a less "organized" ecosystem during EN, which according to Ulanowicz (1986) reflects lower ecosystem growth and development. This result is similar to that of Jarre and Pauly (1993) who estimated a seasonal decrease of cycling in winter and spring, due to lower biomasss and activity of zooplankton and benthos as the principal consumers of detritus. During the LN conditions trophic flows were more articulated, channelling energy flows mainly through anchoveta and showing better adaptation of cold water species to upwelling conditions. Using models before and after the anchovy collapse, Pauly (1987) also mentioned that the Peruvian upwelling ecosystem was better organized before 1972-73 EN than thereaf- 
Table 5

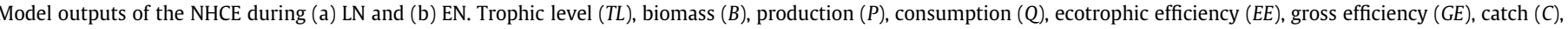
fishing mortality $(F)$, non-predatory mortality $(M 0)$ and predatory mortality $(M 2)$. Parameters in bold were estimated by the model.

\begin{tabular}{|c|c|c|c|c|c|c|c|c|c|c|}
\hline $\begin{array}{l}\text { (a) LN } \\
\text { Functional group/parameter }\end{array}$ & $T L$ & $\begin{array}{l}B \\
\left(\mathrm{t} \mathrm{km}^{-2}\right)\end{array}$ & $\begin{array}{l}P / B \\
\left(\mathrm{y}^{-1}\right)\end{array}$ & $\begin{array}{l}Q / B \\
\left(y^{-1}\right)\end{array}$ & $E E$ & $G E$ & $\begin{array}{l}C \\
\left(\mathrm{t} \mathrm{km}^{-2} \mathrm{y}^{-1}\right)\end{array}$ & $\begin{array}{l}F \\
\left(\mathrm{y}^{-1}\right)\end{array}$ & $\begin{array}{l}\text { M0 } \\
\left(\mathrm{y}^{-1}\right)\end{array}$ & $\begin{array}{l}M 2 \\
\left(\mathrm{y}^{-1}\right)\end{array}$ \\
\hline 1. Diatoms & 1.00 & 53.416 & 265.000 & - & 0.801 & - & 0.000 & 0.000 & 52.690 & 212.310 \\
\hline 2. Dino- and silicoflagellates & 1.00 & 9.426 & 265.000 & - & 0.960 & - & 0.000 & 0.000 & 10.643 & 254.357 \\
\hline 3. Microzooplankton & 2.25 & 20.484 & 256.000 & 1024.000 & 0.950 & 0.250 & 0.000 & 0.000 & 12.800 & 243.200 \\
\hline 4. Mesozooplankton & 2.13 & 31.164 & 40.000 & 125.000 & 0.515 & 0.320 & 0.000 & 0.000 & 19.397 & 20.603 \\
\hline 5. Macrozooplankton & 2.50 & 21.096 & 19.085 & 46.550 & 0.950 & 0.410 & 0.000 & 0.000 & 0.954 & 18.131 \\
\hline 6. Gelatinous zooplankton & 2.98 & 0.017 & 0.584 & 2.920 & 0.950 & 0.200 & 0.000 & 0.000 & 0.029 & 0.555 \\
\hline 7. Macrobenthos & 2.06 & 20.729 & 1.200 & 10.000 & 0.994 & 0.120 & 0.000 & 0.000 & 0.007 & 1.193 \\
\hline 8. Sardine & 3.16 & 7.567 & 1.400 & 14.000 & 0.853 & 0.100 & 7.969 & 1.053 & 0.206 & 0.141 \\
\hline 9. Anchovy & 2.35 & 83.293 & 2.000 & 20.000 & 0.469 & 0.100 & 30.474 & 0.366 & 1.063 & 0.572 \\
\hline 10. Mesopelagics & 3.49 & 6.882 & 1.400 & 14.000 & 0.575 & 0.100 & 0.000 & 0.000 & 0.595 & 0.805 \\
\hline 11. Jumbo squid & 4.18 & 0.524 & 8.910 & 25.457 & 0.940 & 0.350 & 0.186 & 0.354 & 0.534 & 8.021 \\
\hline 12. Other Cephalopods & 3.50 & 6.584 & 4.300 & 12.286 & 0.950 & 0.350 & 0.055 & 0.008 & 0.215 & 4.077 \\
\hline 13. Other small pelagics & 2.77 & 7.804 & 1.000 & 10.000 & 0.950 & 0.100 & 0.688 & 0.088 & 0.050 & 0.862 \\
\hline 14. Horse mackerel & 3.57 & 11.568 & 1.200 & 12.000 & 0.130 & 0.100 & 1.451 & 0.125 & 1.044 & 0.031 \\
\hline 15. Mackerel & 3.59 & 8.488 & 0.850 & 8.500 & 0.048 & 0.100 & 0.096 & 0.011 & 0.809 & 0.029 \\
\hline 16. Other large pelagics & 3.60 & 0.589 & 0.850 & 8.500 & 0.503 & 0.100 & 0.250 & 0.425 & 0.422 & 0.003 \\
\hline 17. Small hake & 3.77 & 2.771 & 0.928 & 6.187 & 0.623 & 0.150 & 0.975 & 0.352 & 0.350 & 0.226 \\
\hline 18. Medium hake & 3.66 & 0.414 & 1.627 & 10.847 & 0.394 & 0.150 & 0.218 & 0.526 & 0.987 & 0.114 \\
\hline 19. Large hake & 4.32 & 0.055 & 1.044 & 6.960 & 0.295 & 0.150 & 0.017 & 0.307 & 0.736 & 0.001 \\
\hline 20. Flatfishes & 3.60 & 0.040 & 0.304 & 2.027 & 0.821 & 0.150 & 0.006 & 0.158 & 0.055 & 0.091 \\
\hline 21. Small demersals & 2.45 & 7.089 & 2.300 & 15.333 & 0.950 & 0.150 & 0.019 & 0.003 & 0.115 & 2.182 \\
\hline 22. Benthic elasmobranchs & 3.48 & 0.078 & 1.000 & 6.667 & 0.401 & 0.150 & 0.031 & 0.401 & 0.599 & 0.000 \\
\hline 23. Butter fishes & 2.44 & 0.032 & 0.800 & 4.000 & 0.039 & 0.200 & 0.000 & 0.000 & 0.768 & 0.032 \\
\hline 24. Conger & 4.21 & 0.019 & 0.750 & 5.000 & 0.823 & 0.150 & 0.000 & 0.000 & 0.132 & 0.618 \\
\hline 25. Medium demersal fish & 3.38 & 0.200 & 1.320 & 8.800 & 0.997 & 0.150 & 0.125 & 0.626 & 0.005 & 0.690 \\
\hline 26. Medium sciaenids & 3.24 & 0.369 & 0.746 & 4.973 & 0.859 & 0.150 & 0.067 & 0.181 & 0.105 & 0.459 \\
\hline 27. Sea robin & 3.49 & 0.789 & 3.400 & 17.000 & 0.897 & 0.200 & 0.000 & 0.000 & 0.351 & 3.049 \\
\hline 28. Catfish & 3.31 & 0.577 & 0.900 & 6.000 & 0.893 & 0.150 & 0.068 & 0.118 & 0.096 & 0.686 \\
\hline 29. Chondrichthyans & 4.74 & 0.027 & 0.486 & 3.240 & 0.508 & 0.150 & 0.007 & 0.247 & 0.239 & 0.000 \\
\hline 30. Seabirds & 3.39 & 0.067 & 0.040 & 60.000 & 0.000 & 0.001 & 0.000 & 0.000 & 0.040 & 0.000 \\
\hline 31. Pinnipeds & 3.45 & 0.072 & 0.100 & 45.900 & 0.000 & 0.002 & 0.000 & 0.000 & 0.100 & 0.000 \\
\hline 32. Cetaceans & 4.25 & 0.062 & 0.100 & 20.000 & 0.000 & 0.005 & 0.000 & 0.000 & 0.100 & 0.000 \\
\hline 33. Detritus & 1.00 & & - & - & 0.814 & - & 0.000 & 0.000 & 0.000 & 0.000 \\
\hline (b) EN 1. Diatoms & 1.00 & 14.761 & 210.000 & - & 0.945 & - & 0.000 & 0.000 & 11.652 & 198.348 \\
\hline 2. Dino- and silicoflagellates & 1.00 & 17.328 & 210.000 & - & 0.841 & - & 0.000 & 0.000 & 33.286 & 176.714 \\
\hline 3. Microzooplankton & 2.18 & 6.572 & 256.000 & 1024.000 & 0.950 & 0.250 & 0.000 & 0.000 & 12.800 & 243.200 \\
\hline 4. Mesozooplankton & 2.24 & 17.000 & 40.000 & 125.000 & 0.947 & 0.320 & 0.000 & 0.000 & 2.104 & 37.896 \\
\hline 5. Macrozooplankton & 2.12 & 34.773 & 19.085 & 46.550 & 0.950 & 0.410 & 0.000 & 0.000 & 0.954 & 18.131 \\
\hline 6. Gelatinous zooplankton & 3.00 & 0.003 & 0.584 & 2.920 & 0.950 & 0.200 & 0.000 & 0.000 & 0.029 & 0.555 \\
\hline 7. Macrobenthos & 2.06 & 25.605 & 1.200 & 10.000 & 0.995 & 0.120 & 0.000 & 0.000 & 0.006 & 1.194 \\
\hline 8. Sardine & 2.99 & 8.318 & 1.400 & 14.000 & 0.396 & 0.100 & 3.334 & 0.401 & 0.846 & 0.153 \\
\hline 9. Anchovy & 3.17 & 33.340 & 2.000 & 20.000 & 0.679 & 0.100 & 14.477 & 0.434 & 0.642 & 0.924 \\
\hline 10. Mesopelagics & 3.12 & 22.375 & 1.400 & 14.000 & 0.137 & 0.100 & 0.000 & 0.000 & 1.208 & 0.192 \\
\hline 11. Jumbo squid & 4.14 & 0.243 & 8.910 & 25.457 & 0.853 & 0.350 & 0.014 & 0.058 & 1.305 & 7.547 \\
\hline 12. Other Cephalopods & 3.14 & 0.227 & 4.300 & 12.286 & 0.950 & 0.350 & 0.012 & 0.053 & 0.215 & 4.032 \\
\hline 13. Other small pelagics & 2.85 & 21.419 & 1.000 & 10.000 & 0.950 & 0.100 & 2.357 & 0.110 & 0.050 & 0.840 \\
\hline 14. Horse mackerel & 2.60 & 3.030 & 1.200 & 12.000 & 0.616 & 0.100 & 1.937 & 0.639 & 0.461 & 0.100 \\
\hline 15. Mackerel & 3.74 & 6.892 & 0.850 & 8.500 & 0.279 & 0.100 & 1.345 & 0.195 & 0.613 & 0.042 \\
\hline 16. Other large pelagics & 3.99 & 1.757 & 0.400 & 4.000 & 0.687 & 0.100 & 0.351 & 0.200 & 0.125 & 0.075 \\
\hline 17. Small hake & 3.59 & 1.245 & 1.317 & 8.780 & 0.909 & 0.150 & 0.556 & 0.447 & 0.120 & 0.751 \\
\hline 18. Medium hake & 3.89 & 0.163 & 1.946 & 12.973 & 0.354 & 0.150 & 0.107 & 0.656 & 1.257 & 0.033 \\
\hline 19. Large hake & 4.51 & 0.028 & 1.516 & 10.107 & 0.286 & 0.150 & 0.012 & 0.429 & 1.082 & 0.005 \\
\hline 20. Flatfishes & 4.14 & 0.010 & 0.304 & 2.027 & 0.882 & 0.150 & 0.001 & 0.100 & 0.036 & 0.168 \\
\hline 21. Small demersals & 2.49 & 4.897 & 2.300 & 15.333 & 0.950 & 0.150 & 0.016 & 0.003 & 0.115 & 2.182 \\
\hline 22. Benthic elasmobranchs & 3.33 & 0.045 & 1.000 & 6.667 & 0.933 & 0.150 & 0.042 & 0.933 & 0.067 & 0.000 \\
\hline 23. Butter fishes & 2.64 & 0.006 & 0.800 & 4.000 & 0.845 & 0.200 & 0.000 & 0.000 & 0.124 & 0.676 \\
\hline 24. Conger & 4.12 & 0.004 & 0.750 & 5.000 & 0.000 & 0.150 & 0.000 & 0.000 & 0.750 & 0.000 \\
\hline 25. Medium demersal fish & 3.11 & 0.211 & 2.480 & 16.533 & 0.905 & 0.150 & 0.144 & 0.682 & 0.236 & 1.561 \\
\hline 26. Medium sciaenids & 3.50 & 0.218 & 1.085 & 7.233 & 0.977 & 0.150 & 0.043 & 0.197 & 0.024 & 0.863 \\
\hline 27. Sea robin & 3.27 & 0.319 & 3.220 & 16.100 & 0.052 & 0.200 & 0.000 & 0.000 & 3.054 & 0.166 \\
\hline 28. Catfish & 3.01 & 0.650 & 0.900 & 6.000 & 0.937 & 0.150 & 0.544 & 0.837 & 0.057 & 0.006 \\
\hline 29. Chondrichthyans & 4.40 & 0.078 & 0.486 & 3.240 & 0.501 & 0.150 & 0.019 & 0.244 & 0.242 & 0.000 \\
\hline 30. Seabirds & 4.01 & 0.010 & 0.040 & 60.000 & 0.000 & 0.001 & 0.000 & 0.000 & 0.040 & 0.000 \\
\hline 31. Pinnipeds & 3.86 & 0.053 & 0.100 & 45.900 & 0.000 & 0.002 & 0.000 & 0.000 & 0.100 & 0.000 \\
\hline 32. Cetaceans & 4.05 & 0.067 & 0.100 & 20.000 & 0.000 & 0.005 & 0.000 & 0.000 & 0.100 & 0.000 \\
\hline 33. Detritus & 1.00 & - & - & - & 0.824 & - & 0.000 & 0.000 & 0.000 & 0.000 \\
\hline
\end{tabular}

ter. On a smaller spatial scale, Taylor et al. 2008b also found a similar increase in energetic efficiency and decrease in ecosystem organization at Independencia Bay during EN.
In general, biomass and trophodynamic changes indicated that during 1997-98 EN, the ecosystem temporarily moved from its original optimum operating point (Kay, 1991), but returned to it, in 


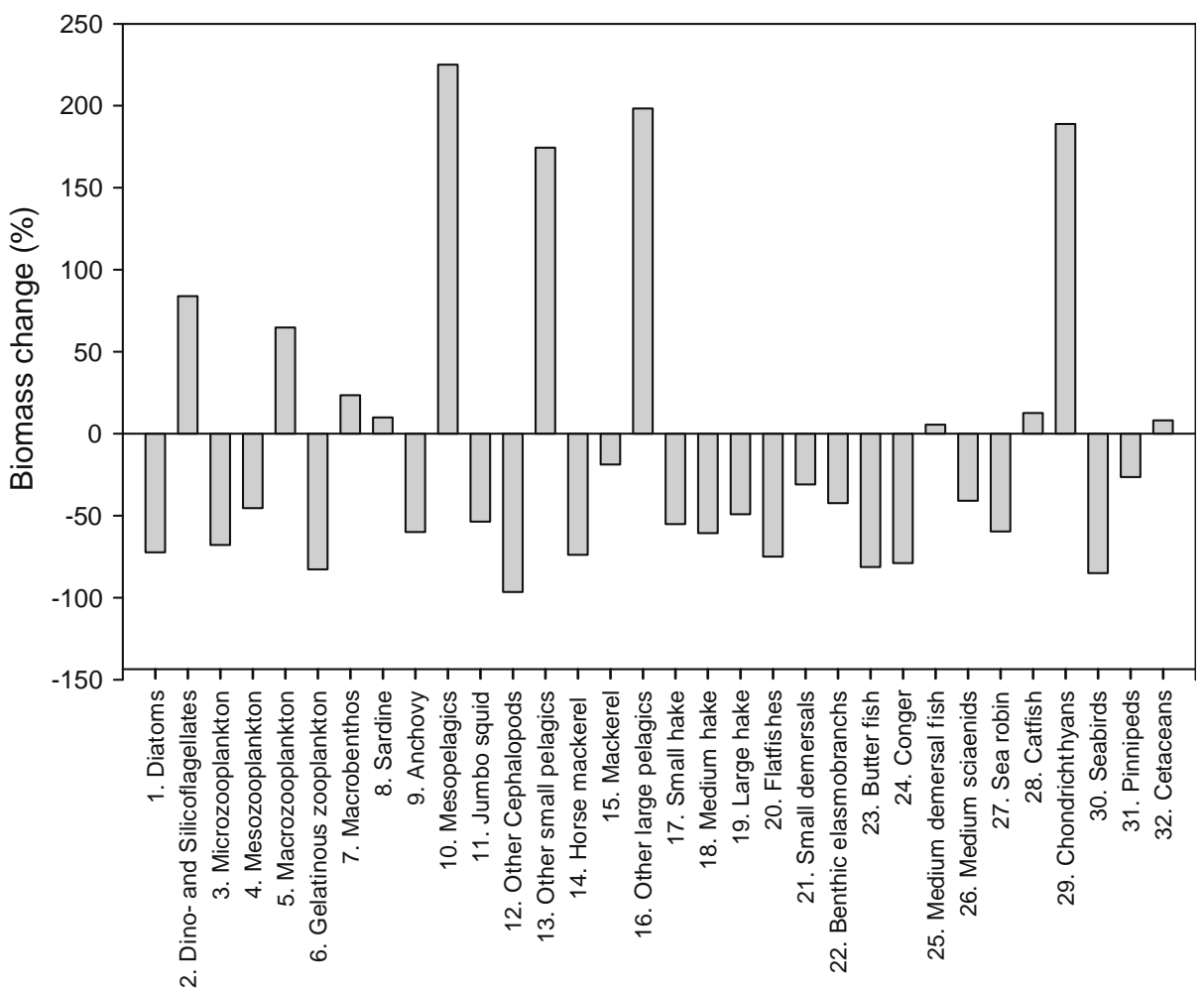

Fig. 2. Percentage biomass changes of functional groups from $L N$ to EN.

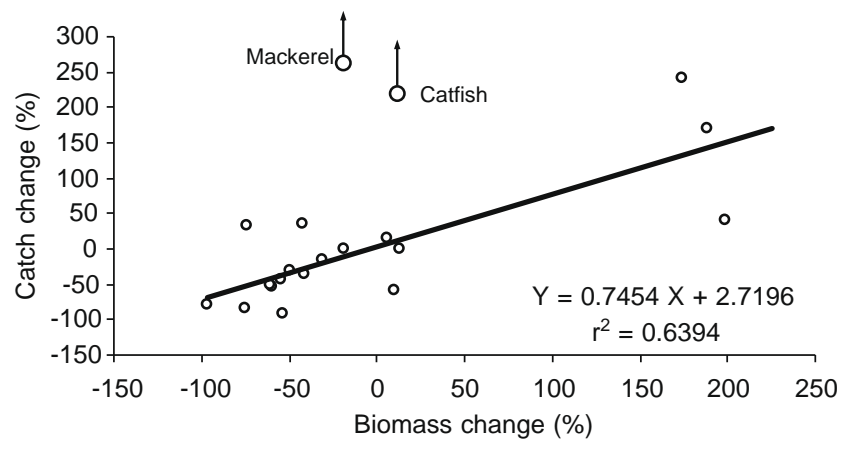

Fig. 3. Relationship between percentage biomass changes and percentage catch changes (excluding mackerel and catfish) from LN to EN.

agreement with the consideration that EN is a typical perturbation to the NHCE.

\section{Conclusions}

While past ecotrophic modeling efforts in the NHCE dealt with interdecadal changes (Jarre et al., 1991), this study focused on the interannual changes associated with El Niño and the Southern Oscillation (ENSO) cycle. The main finding of previous models was a decrease in relative ascendency from the 1950s to the 1970s, after the decline of the anchoveta, which led to an increase in parallel energy transfer and food web connectance, as energy flows through anchovy were channeled through other species. Our models, with increased details in the planktonic and demersal groups, and incorporation of mesopelagic fishes and jumbo squid, determined three main impacts of EN on the food web: (i) dramatic
Table 6

Comparison of ecosystem indicators from models of the NHCE for both periods, including \% change from LN to EN. Values in brackets are in percent of Total system throughput.

\begin{tabular}{|c|c|c|c|}
\hline Ecosystem indicators & LN & EN & $\begin{array}{l}\% \\
\text { Change }\end{array}$ \\
\hline \multicolumn{4}{|l|}{ Trophic indicators } \\
\hline Total system throughput $\left(\mathrm{t} \mathrm{km}^{-2} \mathrm{yr}^{-1}\right)$ & 55,689 & 22,986 & -58.7 \\
\hline Sum of all consumption $\left(\mathrm{t} \mathrm{km}^{-2} \mathrm{yr}^{-1}\right)$ & $\begin{array}{l}28,478 \\
(51.1 \%)\end{array}$ & $\begin{array}{l}12,259 \\
(53.3 \%)\end{array}$ & -57.0 \\
\hline Sum of all exports $\left(\mathrm{t} \mathrm{km}^{-2} \mathrm{yr}^{-1}\right)$ & $2004(3.6 \%)$ & $718(3.1 \%)$ & -64.1 \\
\hline Sum of all respiratory flows $\left(\mathrm{t} \mathrm{km}^{-2} \mathrm{yr}^{-1}\right)$ & $\begin{array}{l}14,688 \\
(26.4 \%)\end{array}$ & $\begin{array}{l}6065 \\
(26.4 \%)\end{array}$ & -58.7 \\
\hline Sum of all flows into detritus $\left(\mathrm{t} \mathrm{km}^{-2} \mathrm{yr}^{-1}\right)$ & $\begin{array}{l}10,519 \\
(18.9 \%)\end{array}$ & $\begin{array}{l}3944 \\
(17.2 \%)\end{array}$ & -62.5 \\
\hline Sum of all production $\left(\mathrm{t} \mathrm{km}^{-2} \mathrm{yr}^{-1}\right)$ & 23,847 & 9957 & -58.2 \\
\hline Total net primary production $\left(\mathrm{t} \mathrm{km}^{-2} \mathrm{yr}^{-1}\right)$ & 16,653 & 6739 & -59.5 \\
\hline Net system production $\left(\mathrm{t} \mathrm{km}^{-2} \mathrm{yr}^{-1}\right)$ & 1965 & 674 & -65.7 \\
\hline Total biomass (excluding detritus) $\left(\mathrm{t} \mathrm{km}^{-2}\right)$ & 302 & 222 & -26.7 \\
\hline Mean transfer efficiency (II-IV) & 10.17 & 11.72 & 15.2 \\
\hline Connectance index & 0.168 & 0.174 & 3.6 \\
\hline System omnivory index & 0.203 & 0.190 & -6.4 \\
\hline \multicolumn{4}{|l|}{ Fishery indicators } \\
\hline Total catches $\left(\mathrm{t} \mathrm{km}^{-2} \mathrm{yr}^{-1}\right)$ & 42.70 & 25.31 & -40.7 \\
\hline Mean trophic level of the catch & 2.62 & 3.12 & 19.1 \\
\hline $\begin{array}{l}\text { Gross efficiency (catch/total net primary } \\
\text { production) }\end{array}$ & 0.0026 & 0.0038 & 46.5 \\
\hline Total catch/total biomass & 0.14 & 0.11 & -19.2 \\
\hline Pelagic/demersal catches & 26.98 & 16.28 & -39.7 \\
\hline $\operatorname{PPR}\left(\mathrm{t} \mathrm{km}^{-2} \mathrm{yr}^{-1}\right)$ & 2420.1 & 1995.6 & -17.5 \\
\hline PPR/total primary produciton (\%) & 14.5 & 29.6 & 103.8 \\
\hline $\mathrm{PPR} /$ catch & 56.675 & 78.844 & 39.1 \\
\hline \multicolumn{4}{|l|}{ Energetic indicators } \\
\hline System primary production/respiration & 1.134 & 1.111 & -2.0 \\
\hline System primary production/biomass & 55.089 & 30.403 & -44.8 \\
\hline System biomass/throughput & 0.005 & 0.010 & 100.0 \\
\hline \multicolumn{4}{|l|}{ Network indicators } \\
\hline Finn's cycling index & 12.61 & 7.49 & -40.6 \\
\hline Ascendency/development capacity (\%) & 46.2 & 40.4 & -12.6 \\
\hline
\end{tabular}


LN

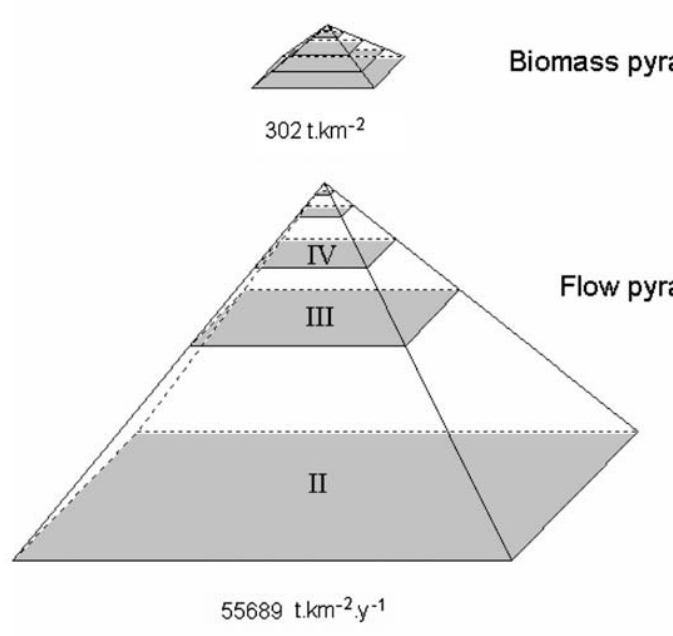

Catch pyramid

$42.70 \mathrm{t} . k m^{-2} \cdot \mathrm{y}^{-1}$
EN

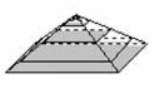

$222 \mathrm{t} . \mathrm{km}^{-2}$

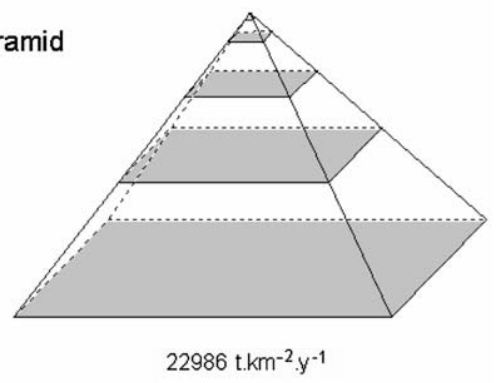

values of biomass, energy flow or catch.

but temporary shrinking of ecosystem size in terms of flows and ecosystem organization, (ii) slight changes in overall functioning (i.e. proportion of energy flows used for respiration, consumption by predators, detritus and export), and (iii) use of alternate pathways through more zooplankton predation on primary producers, leading to a higher impact of the fishery on ecosystem flows. Con- sequently, trophic level of piscivorous groups also increased. Sardine consumption of diatoms and dinoflagellates increased in order to compensate for the increased competition with anchovy for zooplankton, and because sardines are more efficient removers of small particles than anchovy (van der Lingen et al., 2006). A high biomass of macrozooplankton was needed to balance the con-
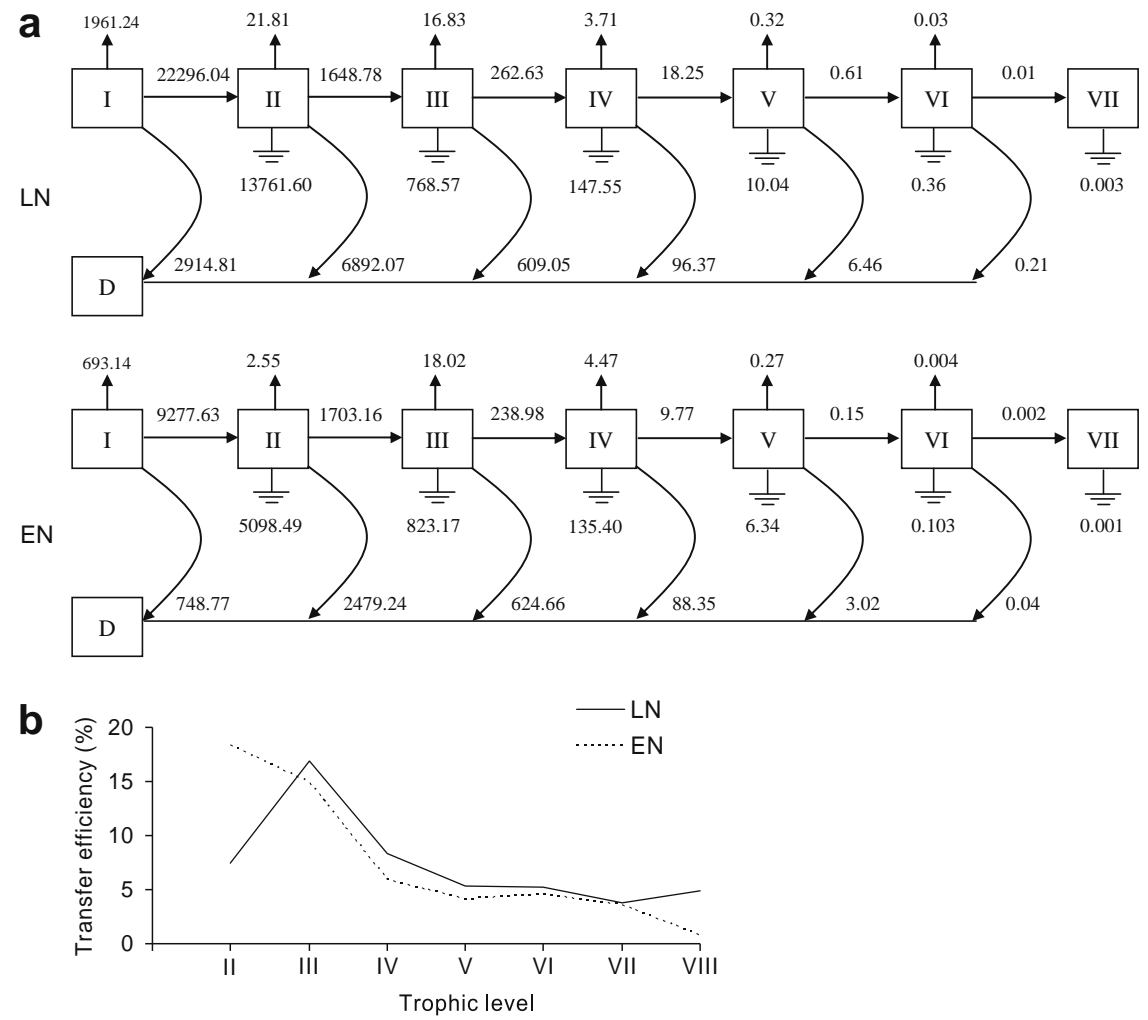

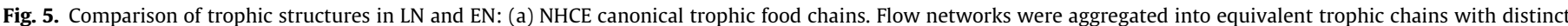

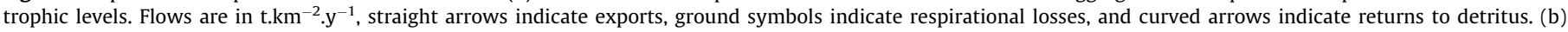
Transfer efficiencies by discrete trophic levels. 
sumption by planktivores, especially during EN conditions when diatoms diminish dramatically. In these conditions, macrozooplankton consumed the remaining phytoplankton left by the reduced anchovy population. EN increased temporarily the trophic level of the catch, and despite lower catches, the higher PPR/catch ratio implied a stronger ecological impact of the fishery, which stresses the need for precautionary management during and after EN. Energetic indicators showed lower system primary production/biomass ratio during EN indicating a more energetically efficient ecosystem, however network indicators showed a lower cycling index, especially at higher trophic levels, and relative ascendency suggesting a less organized ecosystem during EN conditions. These results give support to our general hypothesis that EN is a typical perturbation in the NHCE.

\section{Acknowledgements}

We want to thank Renato Guevara, Miguel Ñiquen, Mariano Gutiérrez, Carmen Yamashiro and Sonia Sánchez from IMARPE, for the shared information. We also thank Arnaud Bertrand and Timothée Brochier from the Institute of Research for Development (IRD) for discussions on anchovy ecology, the staff of the Oceanographic and Fishery Biological Modelling Research Center (CIMOBP, IMARPE) and the staff of the CENSOR project for their helpful comments. We also thank Dr. Lynne Shannon, Dr. J. Timothy Pennington and an anonymous referee for their critical suggestions on the manuscript. This study was partly financed and conducted in the frame of the EU-project CENSOR (Climate variability and El Niño Southern Oscillation: Impacts for natural resources and management, contract No. 511071) and is CENSOR publication No. 0085.

\section{References}

Aguilar, P. (Ed.), 1999. Fórum El Fenómeno El Niño 1997-98: evolución, pronóstico y mitigación. Informe Final. Publicación Espéciale del Instituto del Mar del Perú, Lima, 150p.

Alamo, A., Navarro, I., Espinoza, P., Zubiate, P., 1996a. Relaciones tróficas, espectro alimentario y ración de alimentación de las principales especies pelágicas en el verano de 1996. Informe del Instituto del Mar del Perú 122, 36-46.

Alamo, A., Navarro, I., Espinoza, P., Zubiate, P., 1996b. Espectro alimentario y ración de alimentación de Engraulis ringens y de Sardinops sagax sagax, y mortalidad de huevos de la anchoveta peruana por predación. Informe del Instituto del Mar del Perú 119, 34-42.

Alamo, A., Espinoza, P., 1998. Variaciones alimentarias en Engraulis ringens y otros recursos pelágicos durante invierno - primavera de 1997. Informe del Instituto del Mar del Perú 130, 45-52.

Alamo, A., Espinoza, P., Zubiate, P., Navarro, I., 1997a. Comportamiento alimentario de la anchoveta peruana, Engraulis ringens, durante el invierno de 1996. Crucero BIC Humboldt 9608-09. Informe del Instituto del Mar del Perú 123, 38-96.

Alamo, A., Espinoza, P., Zubiate, P., Navarro, I., 1997b. Comportamiento alimentario de los principales recursos pelágicos peruanos en verano y comienzos de otoño 1997. Informe del Instituto del Mar del Perú 127, 82-89.

Alegre, A., Blaskovic, V., Castillo, C., Espinoza, P., Fernández, F., Flores, R., Peraltilla, S., Tafur, R., Tam, J., Taylor, M., Yamashiro, C., 2005. Comportamiento alimentario del calamar gigante (Dosidicus gigas), enfatizando la depredación ejercida sobre la merluza (Merluccius gayi peruanus). Informe Interno del Instituto del Mar del Perú, 36p.

Alheit, J., Niquen, M., 2004. Regime shifts in the Humboldt Current Ecosystem. Progress in Oceanography 60, 201-222.

Antezana, T., 2002a. Adaptive behavior of Euphausia mucronata in relation to the oxygen minimum layer of the Humboldt Current. In: Färber Lorda, J. (Ed.), Oceanography of the Eastern Pacific. Editorial CICESE, Mexico, pp. 29-40.

Antezana, T., 2002b. Vertical distribution and diel migration of Euphausia macronata in the oxygen minimum layer of the Humboldt Current. In: Färber Lorda, J. (Ed.), Oceanography of the Eastern Pacific II. Editorial CICESE, Mexico, pp. $13-28$.

Arancibia, H., Neira, S., Christensen, V., Olson, R., Arreguín-Sánchez, F., Cubillos, L., Quiñones, R., Gatica, C., Medina, M., 2003. Enfoque metodoldgico para el analisis ecosistemico en la administraction de pesquerias de la zona central de chile. Informe Final Proyecto FIP, 2001-29, 278p.

Arias-Schreiber, M., 2003. Prey spectrum and feeding behaviour of two sympatric pinnipeds (Arctocephalus australis and Otaria flavencens) in relation to the 199798 ENSO in southern Peru. MSc., University of Bremen, Bremen, Germany.

Arntz, W.E., Fahrbach, E., 1991. El Niño: experimento climático de la naturaleza, causas físicas y efectos biológicos. Fondo de Cultura Económica, Mexico, 309p.
Au, D.W., Smith, S.E., 1997. A demographic method with population density compensation for estimating productivity and yield per recruit of the leopard shark (Triakis semifasciata). Canadian Journal of Fisheries and Aquatic Sciences 54, 415-420.

Ayón, P., Arones, K., 1997a. Características generales del zooplancton en la costa norte centro durante el crucero BIC SNP-1 9607-08. Informe del Instituto del Mar del Perú 124, 51-56.

Ayón, P., Arones, K., 1997b. Comunidades de zooplancton e ictioplancton frente a la costa norte-centro del Perú Crucero BIC Humboldt 9705-06. Informe del Instituto del Mar del Perú 128, 70-79.

Ayón, P., Criales-Hernandez, M.I., Schwamborn, R., Hirche., H.-J., 2008. Zooplankton research off Peru: a review. Progress in Oceanography 79, 238-255.

Ballón, M., 2005. Comparative analysis of the community structure and trophic relations of the Peruvian hake Merluccius gayi peruanus and its by-catch of the years 1985 and 2001. MSc. Thesis. University of Bremen, 74p.

Bello, R., Arias-Schreiber, M., Sánchez, R., 1998. Distribución y abundancia relativa de cetáceos durante el Crucero BIC Humboldt 9709-10, de Matarani a Paita. Informe del Instituto del Mar del Perú 130, 78-85.

Bertrand, A., Segura, M., Gutiérrez, M., Vásquez, L., 2004. From small-scale habitat loopholes to decadal cycles: a habitat-based hypothesis explaining fluctuation in pelagic fish populations off Peru. Fish and Fisheries 5, 296-316.

Blaskovic, V., Torriani, F., Navarro, I., 1998. Características tróficas de las principales especies pelágicas durante el otoño 1998. Crucero BIC Jose Olaya Balandra 9805-06 de Tacna a Máncora. Informe del Instituto del Mar del Perú 137, 7279

Blaskovic, V., Espinoza, P., Torriani, F., Navarro, I., 1999. Hábitos alimentarios de la anchoveta frente al litoral peruano durante la primavera 98. Crucero BIC José Olaya Balandra 9811-12. Informe del Instituto del Mar del Perú 146, 77-86.

Bouchon, M., Cahuin, S., Ñiquen, M., 2001. Fluctuaciones de la ictiofauna pelágica en la región norte-centro del litoral peruano de 1994 a 1998. In: Tarazona, J., Arntz, W., Castillo, E. (Eds.), El Niño en América Latina: impact os biológicos y sociales. Consejo Nacional de Ciencia y Tecnología, Lima, Peru, pp. 73-79.

Brown, P.C., Painting, S.J., Cochrane, K.L., 1991. Estimates of phytoplankton and bacterial biomass production in the northern and southern Benguela ecosystems. South African Journal of Marine Science 11, 537-564.

Brush, M.J., Brawley, J.W., Nixon, S.W., Kremer, J.N., 2002. Modeling phytoplankton production: problems with the Eppley curve and an empirical alternative. Marine Ecology Progress Series 238, 31-45.

Calienes, R., Guillén, O., Lostanau, N., 1985. Variabilidad espacio-temporal de clorofila, producción primaria y nutrientes frente a la costa peruana. Boletín del Instituto del Mar del Perú 10, 1-44.

Cardoso, F., Tarazona, J., Paredes, C., 1998. Biological aspects of the Patagonian squid Loligo gahi (Cephalopoda: Loliginidae) in Huarmey, Peru. Revista Peruana de Biología 5, 9-14.

Carr, M.E., 2003. Simulation of carbon pathways in the planktonic ecosystem off Peru during the 1997-1998 El Niño and La Niña. Journal of Geophysical Research 108, 10-1-15.

Christensen, V., Pauly, D., 1992. ECOPATH II a software for balancing steady-state ecosystem models and calculating network characteristics. Ecological Modelling 61, 169-185.

Christensen, V., Pauly, D., 1995. Fish production, catches and the carrying capacity of the world oceans. Naga, The ICLARM Quarterly, 34-40.

Christensen, V., Walters, C., Pauly, D., 2005. Ecopath with Ecosim: a user's guide Fisheries Centre Research Reports 12, 154.

Csirke, J., Guevara Carrasco, R., Cardenas, G., Niquen, M., Chipollini, A., 1996 Situation of the Engraulis ringens and Sardinops sagax resources and perspectives to the fishing in the Peruvian waters, north and central regions of the Peru coast. Boletín del Instituto del Mar del Perú 15, 1-23.

Delgado, E., Sánchez, S., Chang, F., Villanueva, P., Fernández, C., 2001. El fitoplancton frente a la costa peruana durante el Niño 1997-98. In: Tarazona, J., Arntz, W. Castillo, E. (Eds.), El Niño América Latina: impactos biológicos y sociales. CONCYTEC, Lima, pp. 29-38.

Dugdale, R.C., MacIsaac, J.J., 1971. A computational model for the uptake of nitrate in the Peru upwelling region. Investigación Pesquera 35, 299-308.

Espinoza, J., Navarro, I., Torriani, F., 1998a. Variaciones en el espacio alimentario de los principales recursos pelágicos durante otoño 1998. Crucero 9803-05 de Tumbes a Tacna. Informe del Instituto del Mar del Perú 135, 134-142.

Espinoza, P., Blaskovic, V., Navarro, I., 1998b. Comportamiento alimentario de Engraulis ringens, a finales del invierno 1998. Crucero de evaluación hidroacústica de recursos pelágicos 9808-09. Informe del Instituto del Mar del Perú 141, 67-71.

Espinoza, P., Bertrand, A., 2008. Revisiting Peruvian anchovy (Engraulis ringens) trophodynamics provides a new vision of the Humboldt Current system. Progress in Oceanography 79, 215-227.

Frisk, M.G., Miller, T.J., Dulvy, N.K., 2001. Life histories and vulnerability to exploitation of elasmobranchs: Inferences from elasticity, perturbation and phylogenetic analyses. Elasmobranch fisheries: Managing for sustainable use and biodiversity conservation, Dartmouth, NS (Canada). Northwest Atlantic Fisheries Organization.

Guenette, S., Christensen, V., Pauly, D., 2008. Trophic modelling of the Peruvian upwelling ecosystem: towards reconciliation of múltiple datasets. Progress in Oceanography 79, 352-365.

Guillén, V., 1990. Alimentación del pelícano o alcatraz (Pelecanus thagus) en la isla Macabí. Boletín de Lima 67, 85-88.

Gutiérrez, M., 2001. Efectos del evento El Niño 1997-98 sobre la distribución y abundancia de anchoveta (Engraulis ringens). In: Tarazona, J., Arntz, W., Castillo, 
E. (Eds.), El Niño en América Latina: impact os biológicos y sociales. Consejo Nacional de Ciencia y Tecnología, Lima, pp. 55-72.

IMARPE, 2006. Estadísticas pesqueras. En línea: <http://www.imarpe.gob.pe/ imarpe/estadispesquera.php>.

Jahncke, J., Checkley, D.M., Hunt, G.L., 2004. Trends in carbon flux to seabirds in the Peruvian upwelling system: effects of wind and fisheries on population regulation. Fisheries Oceanography 13, 208-223.

Jarre-Teichmann, A., Muck, P., Pauly, D., 1989. Interactions between fish stocks in the Peruvian upwelling ecosystem. ICES 1989 MSM Symposium Paper 27, $24 \mathrm{p}$

Jarre-Teichmann, A., 1998. The potential role of mass balance models for the management of upwelling ecosystems. Ecological Applications 8, S93-S103.

Jarre, A., Muck, P., Pauly, D., 1991. Two approaches for modelling fish stock interactions in the Peruvian upwelling ecosystem. In: Daanand, N., Sissenwine, M.P. (Eds.), Multispecies Models Relevant to Management of Living Resources. ICES Marine Science Symposium 193, pp. 171-184.

Jarre, A., Pauly, D., 1993. Seasonal changes in the Peruvian upwelling ecosystem. In: Christensen, V., Pauly, D. (Eds.), Trophic Models of Aquatic Ecosystems, ICLARM Conference Proceedings, vol. 26, pp. 307-314.

Jarre-Teichmann, A., Christensen, V., 1998. Comparative modelling of trophic flows in four large upwelling ecosystems: global versus local effects. In: Durand, M.H., Cury, Ph., Mendelssohn, R., Roy, C., Bakun, A., Pauly, D. (Eds.), Global versus Local Changes in Upwelling Systems. ORSTOM, Paris, pp. 423-443.

Jarre-Teichmann, A., Shannon, L.J., Moloney, C.L., Wickens, P.A., 1998. Comparing trophic flows in the Southern Benguela to those in other upwelling ecosystems. South African Journal of Marine Science 19, 391-414.

Kaschner, K., 2004. Modelling and Mapping Resource Overlap between Marine Mammals and Fisheries on a Global Scale. Ph.D. thesis, The University of British Columbia, Vancouver, BC, Canada.

Kay, J.J., 1991. A non-equilibrium thermodynamic framework for discussing ecosystem integrity. Environmental Management 15, 483-495.

Majluf, P., 1989. Reproductive ecology of South American fur seals in Peru. In: Pauly, D., Muck, P., Mendo, J., Tsukayama, I. (Eds.), The Peruvian Upwelling Ecosystem: Dynamics and Interactions, ICLARM Conference Proceedings, vol. 18, pp. 332 343.

Moloney, C.L., Jarre, A., Arancibia, H., Bozec, Y.-M., Neira, S., Jean-Paul Roux, J.-P. Shannon, L.J., 2005. Comparing the Benguela and Humboldt marine upwelling ecosystems with indicators derived from inter-calibrated models. ICES Journal of Marine Science 62, 493-502.

Morissette, L., 2007. Complexity, cost and quality of ecosystem models and their impact on resilience: a comparative analysis, with emphasis on marine mammals and the Gulf of St. Lawrence. Ph.D. Thesis, University of British Columbia, Canada.

Muck, P., Fuentes, H., 1987. Sea lion and fur seal predation on the Peruvian anchoveta, 1953 to 1982. In: Pauly, D., Tsukayama, I. (Eds.), The Peruvian Anchoveta and its Upwelling Ecosystem: Three Decades of Change, ICLARM Studies and Reviews, vol. 15, pp. 234-247.

Neira, S., Arancibia, H., Cubillos, L., 2004. Comparative analysis of trophic structure of commercial fishery species off Central Chile in 1992 and 1998. Ecological Modelling 172, 233-248.

Neira, S., Arancibia, H., 2004. Trophic interactions and community structure in the Central Chile marine ecosystem $\left(33-39^{\circ} \mathrm{S}\right)$. Journal of Experimental Marine Biology and Ecology 312, 349-366.

Nigmatullin, C.M., Nesis, K.N., Arkhipkin, A.I., 2001. A review of the biology of the jumbo squid Dosidicus gigas (Cephalopods: Ommastrephidae). Fisheries Research 54, 9-19.

Nixon, S., Thomas, A., 2001. On the size of the Peru upwelling ecosystem. Deep Sea Research I 48, 2521-2528.

NODC (National Oceanographic Data Center), 2001. Taxonomic List of the Arctic Phytoplankton Species. On-line: <http://www.nodc.noaa.gov/OC5/BARPLANK/ WWW/HTML/all_list.html>.

Odum, E.P., 1969. The strategy of ecosystem development. Science 164, 262-270

Ortiz, M., Wolff, M., 2002. Trophic models of four benthic communities in Tongoy bay (Chile): comparative analysis and preliminary assessment of managemen strategies. Journal of Experimental Marine Biology and Ecology 268, 205-235.

Pauly, D., 1987. Managing the Peruvian upwelling ecosystem: a synthesis. In: Pauly, D., Tsukayama, I. (Eds.), The Peruvian Anchoveta and its Upwelling Ecosystem: Three Decades of Change, ICLARM Studies and Reviews, vol. 15, pp. 325-342.

Pauly, D., Christensen, V., Dalsgaard, J., Froese, R., Torres Jr., F., 1998. Fishing Down Marine Food Webs. Science 279, 860-863.
Patterson, K.R., Zuzunaga, J., Cardenas, G., 1992. Size of the South American sardine (Sardinops sagax) population in the northern part of the Peru upwelling ecosystem after collapse of anchoveta (Engraulis ringens) stocks. Canadian Journal of Fisheries and Aquatic Sciences 49, 1762-1769.

Quipuzcoa, L., Marquina, R., 2001. La estructura comunitaria del macrozoobentos en la plataforma continental del Peru: un analisis decadal. In: Espino, M., Samame, M., Castillo, R. (Eds.), Forum La merluza peruana (Merluccius gayi peruanus) biología y pesquería. Informe del Instituto del Mar Perú, pp. 46-49.

Rippe, L., 1996. Gemeinschaftsanalyse des Küstennahen Mesoplanktons im Flachwassergebiet vor der Kolumbianischen Pazifikküste. Diplom thesis, Bremen University, Bremen, Germany.

Sánchez, S., 1996. La comunidad fitoplanctónica en el área de Tambo de Mora a Paita, agosto-setiembre 1995. Informe del Instituto del Mar del Perú 119, 55-69.

Santander, H., Luyo, G., Carrasco, S., Véliz, M., Castillo, O., 1981. Catálogo de zooplancton en el mar peruano. Boletín del Instituto del Mar del Perú 6, 75.

Schetinnikov, A.S., 1989. Food spectrum of the squid Dosidicus gigas (Oegopsida) during ontegenesis. Zoologicheski Zhurnal 68, 28-39.

Sea Around Us, 2006. A global database on marine fisheries and ecosystems. Fisheries Centre, University British Columbia, Vancouver. On-line: <http:// www.seaaroundus.org>.

SERC, 2006. Phytoplankton guide to Chesapeake Bay and other regions. On-line: <http://www.serc.si.edu/labs/phytoplankton/guide/index.jsp>.

Shannon, L.J., Jarre, A., 1999. Comparing models of trophic flows in the northern and southern Benguela upwelling systems during the 1980s. In: Ecosystem Approaches for Fisheries Management. University of Alaska Sea Grant, AK-SG99-01, Fairbanks, pp. 55-68.

Shannon, L.J., Moloney, C.L., Jarre, A., Field, J.G., 2003. Trophic flows in the southern Benguela during the 1980s and 1990s. Journal of Marine Systems 39, 83-116.

Sorokin, Y.I., Kogelschatz, J.E., 1979. Analysis of heterotrophic microplankton in an upwelling area. Hydrobiologia 66, 195-208.

Strickland, J.D., Eppley, R., Mendiola, B., 1969. Poblaciones de fitoplancton, nutrientes y fotosíntesis en aguas costeras peruanas. Boletín del Instituto del Mar del Perú 2, 4-35.

Sun, J., Liu, D., 2003. Geometric models for calculating cell biovolume and surface area for phytoplankton. Journal of Plankton Research 25, 1331-1346.

Tarazona, J., Arntz, W., Castillo, E. (Eds.), 2001. El Niño en América Latina: impactos biológicos y sociales. Consejo Nacional de Ciencia y Tecologia, Lima. 423p.

Taylor, M.H., Tam, J., Blaskovic, V., Espinoza, P., Ballón, R., Wosnitza-Mendo, C., Argüelles, J., Díaz, E., Purca, S., Ochoa, N., Ayón, A., Goya, E., Quipuzcoa, L., Gutiérrez, D., Wolff, M., 2008a. Trophic modeling of the Northern Humboldt Current Ecosystem, Part II: Elucidating ecosystem dynamics from 1995 to 2004 with a focus on the impact of ENSO. Progress in Oceanography 79, 366-378.

Taylor, M., Wolff, M., Mendo, J., Yamashiro, C., 2008b. Comparative analysis of trophic flow structure between normal upwelling and El Niño periods for Bahía Independencia, Peru. Progress in Oceanography.

Tovar, H., Guillen, V., Nakama, M.E., 1987. Monthly population size of three guano bird species off Peru 1953 to 1982. In: Pauly, D., Tsukayama, I. (Eds.), The Peruvian Anchoveta and its Upwelling Ecosystem: Three Decades of Change, ICLARM Studies and Reviews, vol. 15, pp. 208-218.

Ulanowicz, R.E., 1986. Growth and Development: Ecosystems Phenomenology. Springer-Verlag, New York. 203p.

Ulanowicz, R.E., 1997. Ecology, the Ascendent Perspective. Columbia University Press, New York. 201p.

van der Lingen, C.D., Hutchings, L., Field, J.G., 2006. Comparative trophodynamics of anchovy Engraulis encrasicolus and sardine Sardinops sagax in the southern Benguela: are species alternations between small pelagic fish trophodynamically mediated? African Journal of Marine Science 28, 465-477.

Villegas, P., 2001. Growth, life cycle and fishery biology of Loligo gahi (d'Orbigny, 1835) off the Peruvian coast. Fisheries Research 54, 123-131.

Walsh, J.J., Dugdale, R.C., 1971. A simulation model of the nitrogen flow in the Peruvian upwelling system. Investigación Pesquera 35, 309-330.

Walsh, J.J., 1981. A carbon budget for overfishing off Peru. Nature 290, 300-304.

Wangelin, M., Wolff, M., 1996. Comparative biomass of spectra and species composition of the zooplantkton communities in Golfo Dulce and Golfo of Nicoya Pacific coast of Costa Rica. Revista de Biología Tropical 44,135-156.

Wolff, M., 1994. A trophic model for Tongoy Bay - a system exposed to suspended scallop culture (Northern Chile). Journal of Experimental Marine Biology and Ecology 182, 149-168.

Wolff, M., Koch, V., Bautista Chavarria, J., Vargas, J.A., 1998. A trophic flow model of the Golfo de Nicoya, Costa Rica. Revista de Biología Tropical 46 (Suppl. 6), 63-79. 